\title{
Valuation of Urban Air Pollution: A Case Study of Kanpur City in India
}

\author{
USHA GUPTA
}

Bhim Rao Ambedkar College, University of Delhi

Delhi, India

May 2006

South Asian Network for Development and Environmental Economics (SANDEE) PO Box 8975, EPC 1056

Kathmandu, Nepal 
Published by the South Asian Network for Development and Environmental Economics (SANDEE)

PO Box 8975, EPC 1056 Kathmandu, Nepal.

Telephone: 977-1-552 8761, 552 6391 Fax: 977-1-553 6786

SANDEE research reports are the output of research projects supported by the South Asian Network for Development and Environmental Economics. The reports have been

peer reviewed and edited. A summary of the findings of SANDEE reports are also available as SANDEE Policy Briefs.

National Library of Nepal Catalogue Service:

Usha Gupta

Valuation of Urban Air Pollution: A Case Study of Kanpur City in India

(SANDEE Working Papers, ISSN 1893-1891; 2006 - WP 17)

\section{ISBN: 99946-810-5-2}

Key words:

1. Air Pollution

2. Health Damages

3. Mitigating Activities

4. Health-diary

5. Panel Data

6. Health Production Function.

The views expressed in this publication are those of the author and do not necessarily represent those of the South Asian Network for Development and Environmental Economics or its sponsors unless otherwise stated. 


\section{The South Asian Network for Development and Environmental Economics}

The South Asian Network for Development and Environmental Economics (SANDEE) is a regional network that brings together analysts from different countries in South Asia to address environment-development problems. SANDEE's activities include research support, training, and information dissemination. SANDEE is supported by contributions from international donors and its members. Please see www.sandeeonline.org for further information about SANDEE.

SANDEE is financially supported by International Development Research Centre (IDRC), The Ford Foundation, Swedish International Development Cooperation Agency (SIDA) and Norwegian Agency for Development Cooperation (NORAD).

\section{Technical Editor}

Priya Shyamsundar

\section{English Editor}

Carmen Wickramagamage

Comments should be sent to Usha Gupta, Bhim Rao Ambedkar College, University of Delhi , India, Email : ushabishan@yahoo.com 



\section{TABLE OF CONTENTS}

1. INTRODUCTION 1

2. AIR POLLUTION AND HEALTH EFFECTS 3

3. STUDY AREA 5

4. DATA SOURCES AND SURVEY DESIGN 6

5. METHODOLOGY 9

5.1 ESTIMATING THE HOUSEHOLD PRODUCTION FUNCTION 11

5.2 DEMAND FOR MITIGATING ACTIVITY 11

$\begin{array}{ll}5.3 \text { EMPIRICAL SPECIFICATION } & 13\end{array}$

6. RESULTS 14

6.1 WELFARE GAIN 15

6.2 OPPORTUNITY COST OF THE REDUCTION IN WORKDAYS 16 LOST

6.3 REDUCTION IN MITIGATING ACTIVITIES (MEDICAL 16 EXPENDITURE)

7. CONCLUSION AND POLICY IMPLICATIONS 17

8. ACKNOWLEDGEMENTS 18

$\begin{array}{ll}\text { REFERENCES } & 19\end{array}$

TABLES AND FIGURES 22

$\begin{array}{ll}\text { APPENDIX A } & 29\end{array}$

APPENDIX B 32

$\begin{array}{ll}\text { APPENDIX C } & 33\end{array}$

$\begin{array}{ll}\text { APPENDIX D } & 39\end{array}$

\section{LIST OF TABLES}

Table 1 : Estimated Loads of Pollutants of Different Vehicles in Kanpur 22

Table 2 : Point Source Emissions in (kg./ hr.) 22

Table 3 : Emissions from Domestic Fuels 23

Table 4 : Source Distribution of $\mathrm{PM}_{10}(\mathrm{RSPM})$ in Various Areas of Kanpur 23

Table 5 : Distribution of Households in the Sample 23

Table 6 : Summary Information for the Household Survey 24 
Table 7 : Descriptive Statistics of Variables Used in Estimation

Table 8 : Poisson Equations of Workdays Lost $(\mathrm{H})$

Table 9 : Tobit Equations of Mitigating Activities (M) Left Censored (0) 26

Table 10 : Negative Bionomial Equation of Workday Lost $(\mathrm{H})$

\section{ST OF FI GURES}

Figure 1 : Air Pollution in Different Cities in India 27

Figure 2 : Air Quality in Kanpur 27

Figure 3 : Weekly Average of RSPM $(\mu \mathrm{g} / \mathrm{m} 3)$ for the Stated 18 Weeks 28 


\begin{abstract}
This study estimates the monetary benefits to individuals from health damages avoided as a result on reductions in air pollution in the urban industrial city of Kanpur in India. A notable feature of this study is that it uses data from weekly health-diaries collected for three seasons. For measuring monetary benefits, the study considers two major components of health cost - the loss in wages due to workdays lost and the expenditure incurred on mitigating activities. The study estimates that a representative individual from Kanpur would gain Rs 165 per year if air pollution was reduced to a safe level. The extrapolated annual benefits for the entire population in the city are Rs 213 million.
\end{abstract}

Key words: Air Pollution, Health Damages, Mitigating Activities, Health-diary, Panel Data, Health Production Function. 




\title{
Valuation of Urban Air Pollution: A Case Study of Kanpur City in India
}

\author{
Usha Gupta
}

\section{Introduction}

While large-scale industrialization increases the production of material goods and urbanization creates mega cities, the ill effects of these activities are reflected in the form of various environmental problems. One such problem is the deterioration of urban air quality in India and other developing countries. The main contributing factors to air pollution are the overwhelming concentration of vehicles, poor transport infrastructure and the establishment of industries in urban agglomerations. Epidemiological studies have shown that there is a significant association between the concentration of air pollutants and adverse health impacts (Ostro, et al., 1995; MJA, 2004). Air pollution contributes to illnesses like eye irritation, asthma, bronchitis, etc., which invariably reduce efficiency at work.

Among the different types of air pollutants, suspended particulate matter (SPM), especially Respirable Suspended Particulate Matter (RSPM), is recognized as the most important in terms of health effects. ${ }^{1}$ It can penetrate deep into the respiratory tract and cause an increase in cardiac respiratory illnesses, even mortality; contribute to daily prevalence of respiratory symptoms; and decrease pulmonary lung function in children and adults. These illnesses cause functional limitations as reflected by loss of workdays, absence from school, restrictive activity days, and an increase in the visits to doctor and emergency rooms for aggravated asthma and other respiratory illnesses (COMEAP, 1998; M.El-Fadel and M. Masood, 2000; CEAP, 2004). The importance of the link between air pollution and health is underscored in a study by Pope, et al., (2002), who show that residents who live in an area, in California, that is severely impacted by particulate air pollution are at a greater risk of lung cancer at a rate comparable to non-smokers exposed to second-hand smoke. It is observed in this study that there is an excess risk of approximately 16 percent dying from lung cancer due to fine particulate air pollution.

Given the significant impact of air pollution on health, it is important that it be explicitly accounted for in economic planning. This requires, however, economic valuation of the benefits of remedial measures taken to reduce air pollution impacts. Since environmental attributes have the characteristics of public goods, market prices that allow us to estimate the benefits of decreasing air pollution are unavailable. However, using non-market valuation techniques, the benefits of air pollution reduction can be

Well known air pollutants are total suspended particles (TSP), nitrogen oxides $\left(\mathrm{NO}_{\mathrm{x}}\right)$, sulphur dioxide $\left(\mathrm{SO}_{2}\right)$ and respirable suspended particulate matter (RSPM). Particulate Matter (PM) with an aerodynamic diameter of $10 \mathrm{pm}$ or less, known as RSPM or $\mathrm{PM}_{10}$, remains in the atmosphere for longer periods because of its low settling velocity (World Bank, Technical Paper No.737, 1997). 
evaluated. Such economic valuation will enable policy makers to compare benefits of reduced air pollution to the cost of air pollution abatement and to provide inputs for designing policies for air quality improvement and its control mechanism. In developing countries, however, very few studies of this sort have been conducted so far. The proposed study is an attempt to examine air quality improvements and to estimate its health benefits to the people of Kanpur in India.

Kanpur is an important center for trade and commerce in Uttar Pradesh. However, in recent years, Kanpur has acquired notoriety as the second most polluted industrial city in India after Ahmedabad in terms of RSPM concentration, followed by Kolkata, Jaipur, Solapur, Hyderabad, Mumbai, Bangalore and Kochi. ${ }^{2}$ There is evidence of a high percentage of chronic illnesses like asthma, BP, Tuberculosis, heart disease, etc., and this has created widespread concern in Kanpur. One of the main sources of air pollution is the industry associated with textiles, heavy engineering and tanneries. The city is also a major distribution center for finished leather products, textiles and fertilizer. Moreover, lack of opportunities for gainful employment in rural areas has led to an ever-increasing migration of poor families to the urban city of Kanpur resulting in the growth of urban slum clusters and an increase in urban poverty. This has exerted extra pressure on the environmental resources of the city.

In many urban cities of India the pollution levels are much above the international and domestic safety standards. Consequently, in recent years there has been a strong movement to introduce environmental policy changes that can improve air quality. Notable among these policy changes are the recent introduction of Compressed Natural Gas (CNG) in many cities; changes in the mode of transportation from road to rail in Delhi and Kolkata; and relocation of industries in some urban areas. All of these efforts result in significant costs to industries, commuters and the government. Such costs need to be justified on economic grounds.

In response to the obvious problem of air pollution in the city of Kanpur, in the year 1997-98 the Central Pollution Control Board (CPCB) developed an Environmental Management Plan (EMP) for Kanpur with a strong focus on air pollution reduction. As a first step, the city was mapped in terms of land use, location of industries, environmental resource areas, housing quality, water supply, drainage, surface and ground water quality, air quality, solid waste collection status and environmental hotspots. To reduce air pollution, the plan recommended an improvement in the city's road network through the construction of more road corridors and through the regulation of traffic to decongest the residential and market areas. It also proposed the realignment of the Meter-Gauge (MG) Rail Track along the Broad Gauge line. ${ }^{3}$ In fact, the plan recommends a wide range of measures involving very high expenditure to improve environmental quality. These new costly measures underscore the need to estimate the economic benefits of improved air quality in the city.

See Report of the Expert Committee on Auto Fuel Policy, R. A. Mashelkar (August 2002).

The MG Rail Track has been identified as a major source of air pollution. Whenever the train passes through this track, the level of air pollution rises significantly due to traffic congestion at the crossings, which are seventeen in number. 
To estimate the environmental benefits of reduced urban air pollution in Kanpur, this study uses a variant of what is referred to as a household health production function model (HHPF). Essentially, this means that data on expenditure incurred by individuals to lessen the effects of air pollution is taken into account in estimating the health impacts of changes in air quality. The overall impact of air pollution on health is estimated as the sum of mitigating expenditure incurred and the sick days lost as a result of sickness that can be attributed to pollution. A noteworthy feature of this study is the use of health diary data to estimate welfare gains to working individuals from reduced air pollution. To examine the impact of seasonal variations on health, the diary data has been collected for three seasons (winter, summer and monsoon) over an eighteenweek period.

This paper is organized as follows. Section II reviews existing research on air pollution and its health impacts; Section III describes the study area; Section IV gives details of data sources and the design of the household survey; Section V presents methodology; Section VI provides the descriptive statistics of variables used in estimation; Section VII presents the estimates of Poisson and Tobit models and the welfare gains; Section VIII gives the conclusions and discusses some policy implications.

\section{Air Pollution and Health Effects}

There is a vast global literature on air pollution and health. Most of these existing studies on air pollution and health are based on the physical linkage approach, where a dose response function is estimated in order to observe the relationship between human health and air pollution. This relationship is also called the damage function and links air pollution to mortality or morbidity. Well-known among these studies is work by Ostro $(1983 ; 1987)$, who estimated dose response functions to observe the effect of air pollutants on morbidity and showed that particulates affect both restricted activity days (RAD) and work loss days (WLD). His work suggests that a one percent increase in particulate matter will increase WLD by about $0.5 \%$ and RAD by $0.4 \%$.

Another interesting study relevant to this research is by Chestnut, et al., (1997) who compare the results of various studies on health effects and economic valuation conducted in Bangkok, Thailand, concerning particulate matter air pollution. The study compares the willingness to pay for air quality improvements between Bangkok and the $\mathrm{US}^{4}$ and finds that Bangkok residents are willing to pay a higher share of their income to protect their health. A tentative but plausible explanation given here is that health is seen as a basic necessity on par with food and shelter.

Using 1991-92 data for the Republic of China (Taiwan), Alberini and Krupnick (2000) compare the cost of illness (COI) and willingness to pay (WTP) estimates related to health damages from minor respiratory symptoms associated with air pollution. This

The mean WTP value for a symptom day in Bangkok is $\$ 16$ (a sample of 141 adults) while in the $\mathrm{U} S$ it is $\$ 11$ (selected estimates from US studies). For RAD, these values are $\$ 30$ and $\$ 26$ respectively. 
study shows that the ratio of WTP to COI ranges from 1.61 to 2.26 depending on pollution levels. These ratios are similar to those obtained for the $\mathrm{U} S$ in previous studies, despite differences in geographical and socio-economic characteristics between the two countries.

Another relevant study from the developing world is one by M. El-Fadel and Masood (2000) who estimate the economic values of mortality and morbidity for Lebanese urban areas. The total emergency visits avoided due to $10 \mu \mathrm{g} / \mathrm{m}^{3}$ reduction in $\mathrm{PM}_{10}$ are reported to be in the range of $609-25,578$. The corresponding total economic benefit (estimated by using the human capital approach) is reported to be MUS\$ 0.051.9 per year.

In a recent study in India, Murty, et al., (2003) use household data that relates to a recall period of six months. The study analyzes the impact of higher levels of Suspended Particulate Matter (SPM) in the Indian metropolitan cities of Delhi and Kolkata. Using the three stage least square method, a system of simultaneous equations consisting of the health production function and the demand functions for mitigating and averting activities are estimated. The study reveals that the annual marginal benefits to a typical household is Rs 2086 in Delhi and Rs 950 in Kolkata if the level of SPM is reduced from the current average level to the prescribed safe level.

Two other notable Indian studies that estimate benefits of air pollution reduction are a study by Kumar and Rao (2001) in Haryana, India, and Cropper, et al., (1997) using data from Delhi. Kumar and Rao (2001) estimate a dose-response function to measure the economic benefits of improved air quality in the residential complex (consisting 2400 families) of the Panipat Thermal Power Station. Based on an earlier model by Gerking and Stanley (1986), they calculate the monetary costs from morbidity due to higher levels of $\mathrm{PM}_{10}$ emission. This study suggests that for a sixty-seven percent reduction in the level of ambient mean $\mathrm{PM}_{10}$ concentration, which is required to meet National and World Health Organization (WHO) standards, households in Panipat, India are willing to pay on the average an amount that ranges from Rs 12 to Rs 53 per month.

Cropper, et al., (1997) examine the dose-response relationship between a rise in air pollution (in terms of total suspended particulates) and an increase in mortality rates in Delhi, India. While the monetary benefits to the households from reduced air pollution are not estimated in this study, they find that $2.3 \%$ of non-trauma deaths in Delhi are related to a $100 \mu \mathrm{g} / \mathrm{m}^{3}$ increase in Total Suspended Particulate Matter (TSPM). The impact of TSPM non-trauma deaths is found to be statistically significant for the age groups of 5-14 to 45-65 years in Delhi.

All of these studies suggest that there are significant benefits to be derived from reducing air pollution in urban India. This paper examines similar issues in Kanpur. 


\section{Study Area}

Kanpur is the largest and most populous industrial city in the state of Uttar Pradesh in India. According to the 2001 Population Census Data in India, the population of Kanpur was 2.7 million with the annual growth rate at 2.47 percent and population density at 6800 Persons / sq. km. The percentage of the workforce involved in the primary, industrial and service sectors are 4 per cent, 31 per cent and 65 per cent respectively.

The urban limits of Kanpur Nagar are spread over an area of 215 square kms. The city is bound between two rivers, the Ganges in the North and the river Pandu in the south. It is a linear city developed between rivers and the railway lines. Kanpur is famous for its cotton, woolen and leather industries. Kanpur was once known as the "Manchester of Northern India" but over the years has unfortunately gained notoriety as a dirty and polluted city. All the important industries such as textiles, heavy engineering, tanneries, fertilizer and leather are situated in the heart of the city with residential areas on either side. Besides industrial production, the city is a major distribution centre for finished leather products, textiles and fertilizer.

Air pollution in the core areas of Kanpur is five to six times higher than prescribed standards and the level of RSPM $\left(\mathrm{PM}_{10}\right)$ in residential and industrial areas of the city exceeds the National Ambient Air Quality Standards by 200 percent (NAAQS, Appendix B). Figure 1 compares the annual RSPM level in the various cities in India in the year 2000. Kanpur turns out to be the most polluted in terms of residential air pollution, on par with Ahmadabad, but holds second position when it comes to industrial air pollution.

Overwhelming industrial activity and the fleet of mixed vehicles are the two main contributing factors for urban air pollution in the city. Badly maintained roads, a mixed traffic pattern, and, road encroachment aggravate the impact of vehicular pollution in Kanpur. There are about 0.2 million petrol / diesel driven vehicles that ply the roads in Kanpur contributing about 142 MT of pollutants per day. Diesel driven tempos constitute a major portion of the public transport system, causing heavy noise pollution as well as smoke emissions in the city. The Meter Gauge railway track, along the residential areas in the western part of city, has seventeen intersection points, known as Goumti. Whenever the train passes through this track, the level of air pollution goes up by 6 to 8 times due to the increased idling time of vehicles and traffic congestion (CPCB). Table 1 gives the pollution loads of different vehicles in Kanpur. It shows that diesel autos emit the maximum amount of particulate matter (PM) in the city followed by two-wheelers and the intercity movement of goods by road.

The emissions of pollutants such as $\mathrm{SO}_{2}, \mathrm{NO}_{x}$ and $\mathrm{SPM}$ from industrial sources in each of the industrial areas and point source emissions in the city are shown in Table 2. This table shows that emissions of $\mathrm{SO}_{2}, \mathrm{NO}_{2}$ and $\mathrm{SPM}$ from industrial areas such as the Panki power plant, the industrial area and Dada Nagar are quite high. Fly ash generated by the Panki power plant in the Northern part of Kanpur is also one of the major sources of air pollution in the city. 
Another source of air pollution in Kanpur is domestic fuel. Use of coal, wood, cowdung, etc., in the slum settlements and low-income group (LIG) colonies along the railway yard generate localized smoke problems, which affect visibility and cause eye irritation. The estimated pollution load from household fuel is 5.5 MT/Day. Due to stable wind conditions the problem becomes even more severe during winter. Data on emission loads from domestic or household sources are given in Table 3.

The National Environment Energy Research Institute (NEERI) conducted pollution source inventory surveys in the city of Kanpur and submitted its report in July, 2002 (Table 4). NEERI data shows that the highest amount of RSPM is generated by auto exhaust and diesel power generating sets (39\%), followed by re-suspended dust (31\%) and industrial and other sources (25 to $40 \%)$.

Figure 2 provides a geographic sense of the distribution of air pollution. This graph, obtained from the report of Environmental Management Plan (2000) of Kanpur, provides a vivid picture of the condition of air quality in Kanpur. It shows that the entire central part of the city, which is both densely populated and has business centres, is the highly polluted air quality zone. About 60 percent of the geographical area of the city has air pollution problems. It is not surprising that the city is considered one of the hot spots in the country with regard to air pollution.

\section{Data Sources and Survey Design}

The data for the present study was obtained through both household surveys and secondary sources. In October 2003, a pilot survey was conducted to assess the impact of air pollution on the health of residential households in certain randomly chosen areas of urban Kanpur. The sampling frame was constructed based on the Kanpur Development Authority's classification of households. The main survey commenced in January 2004 and was completed in September 2004. The primary data were collected by administering a questionnaire (see Appendix $C$ ) through a face-to-face interview with the head or any other working member of the household. The secondary data, relating to the ambient air quality (RSPM) and weather conditions (temperature and humidity), was collected from the publications of the Central Pollution Control Board (CPCB), U P, Pollution Control Board (UPPCB), and the Department of Meteorology (Chandra Shekhar Azad University of Agriculture, Kanpur).

Monitoring of RSPM in Kanpur by the National Environment and Energy Research Institute (NEERI), the Central Pollution Control Board (CPCB) and the Uttar Pradesh Pollution Control Board (UPPCB) started in the year 2000. The RSPM data for the present study was collected from the records of the CPCB and the UPPCB (from four stations), and covers eighteen weeks over three seasons. The three stations monitored by the UPPCB include residential areas (Deputy Ka Parao, Vikas Nagar, and Kidwai Nagar) while the one monitored by the CPCB is an industrial area (Fazal Ganj) though it is also surrounded by a large residential area. Figure 3 shows season-wise the weekly average of RSPM $\left(\mathrm{mg} / \mathrm{m}^{3}\right)$ at the four monitoring stations in Kanpur. It shows that the level of air pollution is higher than the National Ambient Air Quality 
Standards (NAAQS) at all the locations ${ }^{5}$. Vikas Nagar registers wild fluctuations in the level of RSPM (295 and $463 \mathrm{ig} / \mathrm{m}^{3}$ respectively are the minimum and maximum levels of RSPM) during summer whereas during the monsoon and winter seasons it is as low as 42.5 and $122 \mathrm{ig} / \mathrm{m}^{3}$ (minimum) respectively. The other locations too register fluctuations in the level of RSPM during the three seasons but the volatility is not as high. The reasons for these fluctuations are explained by meteorological and weather conditions.

Different seasons play an important role in determining the ambient concentrations of air pollutants. During the monsoon months (July, August and September), air of oceanic origin causes increased humidity, cloudiness and precipitation. Frequent rains wash away the airborne particulates and other pollutants that are generated and dispersed from different sources. Hence, the period from July to September is supposedly cleaner in terms of RSPM and all the locations register a low level of RSPM during the monsoon period. Winter months (November to February), on the other hand, are dominated by high pressure causing increased atmospheric stability, which allows for both low circulation and stagnant air masses that result in the accumulation of pollutants in the atmosphere. Thus, a more stable atmosphere and slow dispersion of pollutants help build up pollutants in the vicinity of pollution sources. The strong and medium winds during summer (April to June) create turbulent conditions. Local disturbances in the environment cause frequent dust storms and a hazy atmosphere, which build up high levels of particulate matter in the ambient air, mostly soil-borne particles.

Health data were collected through a household survey. The sampling procedure used for the household survey was based on a two-stage stratification-air pollution monitoring stations and the type of accommodation. For the first stage of stratification, we located air pollution monitoring stations in the city. Then, using a meter taxi, an area of one-kilometer radius was marked around each station. During our survey period, there were four functional monitoring stations. Out of these, the one at Vikas Nagar (VN) was maintained by CPCB while the rest at Fazal Ganj (FG), Deputy ka Parao (DKP) and Kidwai Nagar (KN) were managed by UPPCB. We drew a sample of households that contained almost equal numbers of households from each monitoring station area.

The second stage of stratification followed Kanpur Development Authority's (KDA) classification of households based on "types of accommodations", which broadly reflects economic status. According to KDA, 67 percent of the total population lives in a kaccha house, single room or a portion thereof; 21 percent in two-room dwellings; and 12 percent in three or more rooms' dwellings. The sample households of a particular station are distributed across household types in proportion to the number of households in each type. All the households in the marked area around each station were allotted a serial number and random numbers generated by the computer (the lottery system) were used to identify the households to be included in the sample.

5 Safe levels as prescribed by NAAQS are the levels of air quality, with an adequate margin of safety, which are necessary to protect public health, property and vegetation. 
Our final sample consisted of 222 and 163 households residing respectively in oneroom and kaccha houses representing households belonging to the poorest section of the society; 116 households living in two-roomed dwellings, representing the lower middle class category; and 57 and 47 households residing in three- and more than four roomed houses respectively and considered to be of higher income levels. Table 5 shows the distribution of sampled households across the four monitoring stations according to the size of dwellings.

The survey questionnaire used for the household survey had four main sections with detailed subsections to facilitate the collection of relevant data on key variables. Thus, sections 1, 2 and 4 covered various socio-economic and demographic features such as religion, family background, age and sex composition of household members, level of education, marital status, occupation and the size of the accommodation / house. Section 3 provided data on the current health status (symptoms of acute illnesses linked to air pollution exposure) and mitigating and averting activities adopted by all the members in a household for a recall period of one week. Its sub-sections contained information on individuals' past health stock (chronic diseases), their habits that affect health in general and the general awareness of households about the illnesses that occur due to air pollution.

To assess indoor air quality and exposure to indoor air pollution, information on the use of home A.C., cooking gas, exhaust fan or chimney, room heater, home affected by road dust, dampness, mosquito repellent, etc., were also collected. Data on drinking water quality was obtained to account for water-borne illnesses.

In order to collect data on gross annual income, different income brackets were offered to the respondents to select their respective range of income. Data on an alternative measure of wealth of households/individuals in the form of average annual expenditure and inventory of durable consumer items were also collected to crosscheck the income levels.

A unique feature of this study is the Weekly Health Diary, which sought to capture the impact of seasonal variations on health. The diary data was collected for eighteen weeks (six weeks in each season-summer, winter and monsoon) covering working individuals from the targeted households. Trained enumerators visited each of these households, every week, in each season, to fill the diary data on mitigating activities and the workdays lost due to illness. The seasonal phases to which the diary data belongs are: winter season (Jan.'04—Feb.'04); summer season (May '04\%June '04) and the monsoon season (July '04-Sept '04).

With the 18 weeks of health diary data and a total of 3122 household members (consisting of both children and adults), the existing data set results in a panel containing $58,196$ observations ( $3122 \times 18)$. The present study focused on working individuals. The sample included 863 working individuals. However, only 815 working members could be taken into consideration on the basis of availability of full information. 
Table 6 presents summary information on the household survey. Most households in the city report nuclear families as is indicated by the family size (5.2) and the number of married persons. Data on religion shows that most households are Hindu. On average, individuals have six years of education. Eighteen percent of individuals in the sample reported to be smokers.

Coal is used by 28.8 percent of the population for the purposes of cooking and space heating. It generates localized smoke that causes invisibility in the concerned areas (particularly, in slum settlement colonies) as well as indoor air pollution. Thirty two percent households keep indoor plants, particularly Basil plant for religious and medicinal reasons and other plants for decorative purposes. Green plants in earthen pots are watered regularly, which add to the dampness and affect health of households adversely. Chronic patients are 10.2 percent, which represent the poor health stock of the households.

\section{Methodology}

We use the household health production function model to estimate the economic benefits from reduced morbidity due to reduction in air pollution in Kanpur city. The household health production function and the demand function for mitigating activities ${ }^{6}$ that are implicit in the utility maximizing behavior of an individual are based on Freeman (1993) and derived as follows:

An individual's utility function, health production function and the budget constraint may be defined as

$U=U(X, L, H, Q)$

where, $\mathrm{X}$ is the consumption of marketed goods, L denotes leisure time available per period to an individual, $\mathrm{H}$ represents the work days lost per week due to air pollution induced sickness and Q shows the level of ambient air pollution. The individual derives utility from the consumption of $\mathrm{X}$ and $\mathrm{L}$, while $\mathrm{H}$ and $\mathrm{Q}$ result in disutility.

An individual produces good health by combining mitigating activities with the given level of air pollution (Q) given his health status and other socio-economic characteristics.

The household health production function can be written as

$$
H=H(M, Q, Z)
$$

where,

$\mathrm{H}$ : number of work days lost

M: mitigating activities

Q: level of ambient air pollution

$\mathrm{Z}$ : a vector of other health characteristics of an individual

$6 \quad$ The estimated model does not include averting activities because the survey data reveals that people in Kanpur do not adopt averting activities (such as a.c. car, staying indoors, using heater, mask, diverting to cleaner route, etc.,) to avoid exposure to air pollution. 
$\mathrm{H}$ could also represent the individual's health status or number of days of illness. Mitigating activities (M) include the individual's demand for medicines, hospitalization, pathological tests, doctor's consultation and travel to doctor's clinic. The other health characteristics $(Z)$ of an individual are the history of chronic illness, food and other habits. The model assumes that individuals could maintain a given health status even with higher ambient air pollution through the choice of mitigating activities in the market. It means that there are substitution possibilities between mitigating activities and the ambient air quality.

An individual's budget constraint can be specified as:

$$
I=Y+w(T-L-H)=X+P_{M} M
$$

where, $\mathrm{Y}$ is non-wage income; $\mathrm{w}$ is wage rate; $(\mathrm{T}-\mathrm{L}-\mathrm{H})$ is time spent at work (T is total time); $\mathrm{P}_{\mathrm{M}}$ is the price per unit of mitigating activity.

Given the pollution level (Q), prices of mitigating activities $\left(\mathrm{P}_{\mathrm{M}}\right)$, wage rate $(\mathrm{w})$, income (I) and other exogenous variables, individuals maximize (1) with respect to $\mathrm{X}, \mathrm{M}$, and L given the budget constraint (3). By solving the following problem,

$$
\operatorname{Max} G=U(X, L, H, Q)+\lambda\left[Y+w(T-L-H)-X-P_{M} M\right]
$$

where $\lambda$ is the Lagrange multiplier.

We obtain the individual's demand function for mitigating activities, and the marginal willingness to pay function for air quality improvement (MWP) as ${ }^{7}$ :

$$
\begin{aligned}
& M=M\left(P_{m}, H, Q, X, Z\right) \\
& M W T P=w \cdot d H / d Q+P_{M} \cdot \delta M / \delta Q+(\delta u / \delta H) \cdot d H / d Q / \lambda
\end{aligned}
$$

This expression in (6) shows that the MWTP for health benefits from the reduction in pollution is the sum of observable reductions in the cost of illness, cost of mitigating and the monetary equivalent of disutility of illness. The estimation of MWTP requires the estimation of the health production function (2) and the demand function for mitigating activities (5) simultaneously. Alternatively, a reduced form dose-response function with health as a function of pollution and other variables can be estimated. This can be combined with the estimated demand for mitigating behaviour and wage information to obtain a lower bound for (6) (Freeman 1993). This is a lower bound estimate because it does not take into account disutility from sickness (the last expression in (6)).

7 See Freeman (1993)

10 SANDEE Working Paper No. 17-06 


\subsection{Estimating the Household Production Function}

For estimation purposes, there are two salient features of the present data set that need to be taken into account: (i) the dependent variable is a count of the total number of the workdays lost by an individual, due to air pollution induced illnesses, in a given week during the three seasons; (ii) there are repeated observations for the same individuals. Thus, this data forms a combined time-series cross-section panel.

The occurrence of morbidity due to air pollution is not a continuous phenomenon and is discrete in nature. The data collected from the survey provides count events of morbidity, where there are zeros for several observations. In this case, the application of the Poisson regression model is appropriate because it accounts for the preponderance of zeros and the small values and the discrete nature of the dependent variable while least square and the linear models do not take into consideration these characteristics. Thus, for estimating the household health production function, we use a Poisson regression model.

$$
\operatorname{prob}\left(Y_{i t}=y_{i t} / x_{i t}\right)=\mu_{i t}^{y_{i t}} e^{-\mu_{i t}} / y_{i t} ! \quad \mathrm{y}_{\mathrm{it}}=0,1,2, \ldots \ldots \ldots \ldots
$$

The resulting regression model is nonlinear in parameters. By taking the natural log of equation (7) we obtain the following regression model which is linear in parameters,

$\ln \mu_{i t}=\alpha_{i}+\beta_{1} X_{1 i t}+\beta_{2} X_{2 i t}+\ldots \ldots . .+\beta_{s} X_{s i t} \alpha_{i}+b_{2} X_{2 i t}+b_{3} X_{3 i t}+\longleftarrow+b_{\mathrm{S}} X_{\text {Sit }}$

However, it is noted that in practice the Poisson regression model is restrictive in many ways. Firstly, it is based on the assumption that events occur independently over time. The independence assumption may break down, as there may be a form of dynamic dependence between the occurrences of successive events. For example, the prior occurrence of an event, such as workdays lost due to air pollution induced illness, may increase the probability of a subsequent occurrence of the same or similar event. Secondly, the assumption that the conditional mean and variance of $\mathrm{y}_{\mathrm{i}}$, given $\mathrm{X}_{\mathrm{i}}$ are equal, may also be too strong and hence fail to account for over dispersion (the variance exceeds the mean). This restriction may produce small estimated standard errors of the estimated $\beta$. An alternative to scaling the standard errors is to apply the negative binomial distribution, which is attempted in Appendix A.

\subsection{Demand for Mitigating Activity}

An important characteristic of the survey data on mitigating activities is that it has several observations where the medical expenditure is zero. This feature of the data destroys the linearity assumption; hence the application of the least squares method is inappropriate. Also the continuous density to explain the conditional distribution of medical expenditure, given income, cannot be used because a continuous density is 
inconsistent with the fact that the data on mitigating expenditures contains several observations at zero. ${ }^{8}$ Therefore, to estimate the demand for mitigating activities, we use a Tobit model.

$$
\begin{array}{cr}
M_{i t}=\alpha+\beta x_{i t}+u_{i} & \text { if RHS }>0 \\
=0 & \text { otherwise }
\end{array}
$$

where, $M_{i t}$ refers to the probability of the ith household incurring positive mitigating expenditure at time $t$, and $x_{i t}$ denotes a vector of individual characteristics, such as income, age and education, pollution parameters, weather conditions, etc.

In panel data there are two approaches of estimating the above functions (the Household Health Production and the Demand Function for mitigating activities), that is, the fixed effects and random effects models. Panel data contain individual specific heterogeneity, which arises due to unobserved or imperfectly observed differences in individual characteristic / behavior. To handle this heterogeneity, in the fixed effects estimation each individual has its own (fixed) intercept value, that is, in all there are $\mathrm{N}$ such values for $\mathrm{N}$ individuals. The individual intercept captures the combined effect of both observable and unobservable time invariant variables (such as age, income, attitude etc.) but does not identify the impact of such time invariant variables separately. Therefore, in the estimation of fixed effects model we obtain only the values of time variant variables (such as weather conditions etc).

On the other hand in the random effects model the intercept á mean value for the all the (cross-sectional) intercepts and the individual specific error component represents the (random) deviation of individual intercept from this mean value. Thus, the individual differences in the intercept values of each person are reflected in the composite error term ${ }_{\text {ita }}$ in the random effect model (equ.8). The composite error term consists of two components, $e_{i}$, which is the cross-section or individual specific error component, and $u_{i t}$, which is combined time series and crosssection error component. The random effects model assumes that error terms are normally distributed. The individual error components are not correlated with each other and are not auto correlated across both cross-section and time series units.

$$
\begin{aligned}
& \varepsilon_{i} \sim N\left(0, \sigma_{\varepsilon}{ }^{2}\right) \\
& \begin{array}{l}
u_{i t} \sim N\left(0, \sigma_{u}{ }^{2}\right) \\
E\left(\varepsilon_{i} u_{i t}\right)=0 \\
E\left(u_{i t} u_{i s}\right)=E\left(u_{i t} u_{j t}\right)=E\left(\varepsilon_{i t} u_{j s}\right)=0
\end{array} \quad(i \neq j)
\end{aligned}
$$

The individual error component, $\mathrm{e}_{\mathrm{i}}$, is not directly observable so it is termed as latent or unobservable variable.

\footnotetext{
8 T Amemiya (1984), "Tobit Models: A Survey."

12 SANDEE Working Paper No. 17-06
} 


\subsection{Empirical Specification}

Empirically, we estimate the following two reduced form equations consisting of the household health production function and the demand function for mitigating activities to estimate the marginal effect of pollution on $\mathrm{H}$ and $\mathrm{M}$. We use the random effects panel data regression model to estimate both these equations. ${ }^{9}$

$$
\begin{aligned}
& H=\alpha_{i}+\beta_{1} r s p m+\beta_{2} \text { dtemp }+\beta_{3} t \max +\beta_{4} N O_{x}+\beta_{5} S O_{2}+\beta_{6} \text { wind }+\beta_{7} r h \text { min }+\beta_{8} \text { age }+\beta_{9} \text { age }{ }^{2} \\
& +\beta_{10} b c j+\beta_{11} \text { asthma }+\beta_{12} B P+\beta_{13} T B+\beta_{14} \text { heart }+\mathrm{v} \\
& M=\gamma_{i}+\delta_{1} r s p m+\delta_{2} \text { dtemp }+\delta_{3} t \max +\delta_{4} N O_{x}+\delta_{5} S O_{2}+\delta_{6} \text { wind }+\delta_{7} r h \min +\delta_{8} \text { age }+\delta_{9} \text { age }{ }^{2} \\
& +\delta_{10} b c j+\delta_{11} \text { asthma }+\delta_{12} B P+\delta_{13} T B+\delta_{14} \text { heart }+\bar{\Phi}
\end{aligned}
$$

The dependent variables used in the equation are:

Work Lost Days (H): $\mathrm{H}$ represents the number of workdays lost per person per week due to diseases / symptoms associated with air pollution. Mitigating Activities (M): Mitigating activities (M) include expenses incurred as a result of air pollution related diseases. These expenditures include costs of medicines, doctor's fees, diagnostic tests, hospitalization, travel to doctor's clinic, etc., per person, per week.

The independent variables that affect the health production function and mitigating activities are:

Respirable Particulate Matter $\left(\mathrm{PM}_{10}\right)$ : This is the average of the maximum twice-weekly values of RSPM $\left(\mathrm{PM}_{10}\right)$ measured in $\mu \mathrm{g} / \mathrm{m}^{310}$. RSPM remains in the atmosphere for longer periods because of its low settling velocity. It can penetrate deeply into the respiratory tract and cause respiratory illnesses in humans.

The Variation in Temperature (DTEMP): It is the difference of the average values of daily maximum and minimum temperatures. The temperature swings cause acute illnesses like coughing, cold, fever, etc.

Maximum Ambient Temperature (TMAX): It is the weekly average of daily maximum ambient temperature.

Nitrogen Oxides $\left(\mathrm{NO}_{\mathrm{x}}\right)$ : This is the average of maximum twice-weekly values of $\mathrm{NO}_{\mathrm{x}}$ measured in $\mu \mathrm{g} / \mathrm{m}^{3}$. $\mathrm{NO}$ and $\mathrm{NO}_{2}$ are the main components of $\mathrm{NOx}$. It is produced by natural phenomena such as lightning, volcanic eruptions and bacterial action in the soil and by anthropogenic sources such as the combustion of fuels in internal combustion engines, thermal power plants, industrial and heating facilities and incinerators. Exposure to $\mathrm{NO}_{\mathrm{x}}$ is linked with increased susceptibility to respiratory infection; asthma attacks

9 The Hausman test for choosing between the fixed and random effects models is in favor of the random effects model in the estimation of Poisson regression model for work days lost. The Tobit model only estimates the random effects model.

10 In Kanpur the values of pollutants such as $\mathrm{RSPM}, \mathrm{NO}_{\mathrm{x}}, \mathrm{SO}_{2}$, etc. are recorded during two days in each week, with three readings taken on each day. We have taken the maximum value of each day 's readings and averaged them over the two days of readings to find the value for each week. 
and decreased pulmonary function. Short-term exposure is associated with lower respiratory illnesses in children such as cough, sore throat and runny nose, etc.

Sulphur Dioxide $\left(\mathrm{SO}_{2}\right)$ : This is the average of maximum twice-weekly values of $\mathrm{SO}_{2}$ measured in $\mu \mathrm{g} / \mathrm{m}^{3}$. An irritating gas that is absorbed in the nose and aqueous surfaces of the upper respiratory tract, $\mathrm{SO}_{2}$ is associated with reduced lung function and increased risk of mortality and morbidity.

Wind: This is the weekly average of wind speed measured in meter / second. The wind moves air pollutants from one location to another. The extent of dilution of air pollutants depends on wind speed and its direction.

RHMIN: This is the weekly average of minimum relative humidity. Precipitation affects ambient pollutant concentrations because it washes out pollutants, particularly PM from the air.

Age: This refers to the years of age of a working individual. With ageing, the health stock deteriorates and therefore proneness to illness and mitigating activities increase. BCJ: This variable stands for blue-collar jobs. It takes value 1 if a person has a bluecollar job, otherwise it takes 0 . Blue-collar workers are rickshaw-pullers, vegetable vendors, rag pickers and a few other outside workers.

Chronic Illnesses: Chronic illnesses such as Asthma, Blood pressure, Tuberculosis and Heart Disease are taken as dummy variables. It takes the value 1 if an individual has a particular disease, otherwise it takes the value of 0 . This variable accounts for the individual's health stock. An individual who has a chronic illness is more susceptible to air pollution exposure and is likely to have higher medical expenses and number of workdays lost.

Table 7 provides details of descriptive statistics of variables used in the estimation. The average number of workdays lost $(\mathrm{H})$ per week per person is 0.03 . The medical expenditure incurred on these illnesses per week per person is Rs 3.62. The low percentage of absence from work may be due to poor economic conditions. More than sixty seven percent people are in blue-collar jobs. The average age of working individuals is 36.40 years in Kanpur. The number of patients experiencing chronic illnesses such as asthma, tuberculosis, blood pressure and heart ailments are high. They are also more susceptible to rising levels of air pollution.

\section{Results}

The estimated health production function and the demand function for mitigating activities using the Poisson and Tobit regression models are given in Tables 8 and 9. The health production function using a negative binomial regression model for estimating work days lost is given in Appendix $\mathrm{A}^{11}$ Table 8 and 9 provide the parameter estimates of

11 As discussed in the Appendix, this model might be more appropriate for estimating the workdays lost equation if the data shows over dispersion. 
reduced form equations of workdays lost and mitigating expenditures, which are expressed as functions of a common set of physical and socio-economic variables.

The health production function or the equation for work days lost is estimated as a reduced form given in column (2) of Table-8. The coefficients of all three pollution parameters, viz., RSPM, $\mathrm{SO}_{2}$ and $\mathrm{NO}_{\mathrm{x}}$ are positive, with two of them significant (RSPM at one percent level and $\mathrm{SO}_{2}$ at five percent level) depicting an increase in workdays lost as pollution level increases. Weather variables-DTEMP, TMAX and RHMINindicate a decrease in the loss of workdays during clear, hot and less humid weeks. The coefficients of TMAX and RHMIN are significant at one percent level while that of DTEMP is at ten percent level of statistical significance. Socio-economic variables, such as age of the person, individual health history of having asthma, etc., have positive coefficients as expected and are also statistically significant.

Table 9 presents parameter estimates of the reduced form equation of mitigating activities (medical expenditure). The coefficients of pollutants $\mathrm{RSPM}, \mathrm{NO}_{\mathrm{x}}$ and $\mathrm{SO}_{2}$ are positive depicting a reduction in mitigating expenses with the decrease in RSPM, $\mathrm{NO}_{\mathrm{x}}$ and $\mathrm{SO}_{2}$ levels. In the case of RSPM even though its coefficient is not statistically significant at the conventional level, the 95 percent confidence interval is: 0.0345 and 0.2170 . Though the $\mathrm{NO}_{\mathrm{x}}$ and $\mathrm{SO}_{2}$ levels are within the NAAQS limits in Kanpur, both the coefficients are positive. Wind shows dispersion and dilution effect. The coefficient is negative and significant at one percent level. The significant and negative coefficient of DTEMP (variation in temperature) indicates a reduction in mitigating expenses on sunny days. The age effect appears through both $A G E$ and $A G E^{12}$. The coefficient of $A_{G E}{ }^{12}$ is positive whereas for AGESQUARED it is negative. Both the coefficients are significant at one percent level. The marginal effect of age on mitigating expenses is positive at a younger age but is reduced as age progresses.

All chronic diseases ASTHMA, BP, TB, and HEART have positive coefficients and are significant at one percent level, meaning thereby that people with these conditions have higher medical expenditures. The aggravated effects of RSPM on chronic conditions could be captured in this estimation by interacting RSPM with the chronic illnesses. However, none of the interactive terms are statistically significant and were not included in the final model. The coefficient of blue-collar jobs is positive and significant at one percent level suggesting a higher medical expenditure for blue-collar workers as they are exposed to air pollutants at the work place.

\subsection{Welfare Gain}

The welfare gain from reduced urban pollution in Kanpur can be explained in terms of reduction in the opportunity cost of workdays lost and the reduction in the expenditure on mitigating activities. Using the estimated health production function and the demand

12 Coefficient (age) $/ 2 * \operatorname{coeff}\left(\operatorname{age}^{2}\right)=45.91$ years. This is, the threshold value of age that explains that mitigating expenses increase up till 46 years of age and decrease thereafter. 
function for the mitigating activities given in Tables 8 and 9, an estimate of health benefits for the households in Kanpur from reducing air pollution from the current level to the safe level can be estimated.

\subsection{Opportunity cost of the reduction in workdays lost}

Differentiating partially the household health production function with respect to RSPM $(\delta \mathrm{H} / \delta \mathrm{RSPM})$, we obtain the marginal effect, that is, reduction in workdays lost due to the reduction in RSPM levels. The Poisson estimates show that one $\mu \mathrm{g} / \mathrm{m}^{3}$ fall in RSPM results in a marginal gain of 0.00007 for a representative person in a week. By multiplying the marginal gain by $\triangle$ RSPM, i. e., reduction in RSPM from current to the safe level $\left(165.68 \mu \mathrm{g} / \mathrm{m}^{3}\right)$, we obtain an estimate of the gain in workdays for a representative person as 0.0121 . The annual gain in workdays is estimated as 0.6299 . The estimated wage of a working person per day from the sample is Rs 207. Therefore, in monetary terms, the annual gain turns out to be Rs 130.39 per year for a representative working person in Kanpur. Symbolically, it can be written as:

$$
\beta \times \lambda \times \Delta \mathrm{RSPM} \times(365 / 7) \times \mathrm{w}
$$

where, $\beta$ is estimated coefficient, $\lambda$ is the predicted value of $H, \Delta R S P M$ is the change in the level of air pollutant (RSPM) from current to the safe level and $w$ is the average wage rate. ${ }^{13}$

Our data shows that working members constitute 28 percent of people in the sample. Using the same percentages to extrapolate to the total population of Kanpur of 3 million, the total number of working people in Kanpur is estimated as 0.84 million. By extrapolating the welfare gains to the entire working population of Kanpur, the annual gains from savings in work days lost are estimated as Rs. 109.53 million.

\subsection{Reduction in mitigating activities (medical expenditure)}

Differentiating partially the equation of mitigating activities with respect to RSPM, and multiplying it by the probability of the dependent variable-M-taking the non-zero values we obtain the marginal effect. The marginal effect indicates reduction in mitigating activities (medical expenditure) for a unit reduction in the level of RSPM. If the level of RSPM is reduced from the current to the safe level, per annum reduction in medical expenditure turns out to be Rs 34.43 for a representative person. Symbolically:

$$
(\delta \mathrm{M} / \delta \mathrm{RSPM}) \times \mathrm{P}\{\mathrm{y}>0\} \times \Delta \mathrm{RSPM} \times(365 / 7)
$$

where, $(\delta \mathrm{M} / \delta \mathrm{RSPM})(\mathrm{p}\{\mathrm{M}>0\})$ is the marginal effect and the probability of y being positive. Extrapolating this gain to the entire population in Kanpur, it is estimated as Rs 103.29 million per annum.

13 The Poisson regression estimates (Table 8) provide $\hat{\mu}_{i}=\mathrm{e}_{0}^{\beta}{ }^{\beta}{ }_{1}^{\beta}$ rspm $+\ldots$. To find out the marginal effect of a unit increase in the level of RSPM on mean H, we compute $\frac{\delta \mu}{\delta r s p m_{1}}=\beta_{1} \mathrm{e}_{0}^{\beta}$ $+{ }^{\beta}{ }_{1} \mathrm{rspm}+{ }_{2}{ }_{2} \mathrm{dtemp}+\ldots+\beta_{14}$ heart $=\beta \mu$. Thus, the marginal effect of RSPM is equal to the coefficient of RSPM times the predicted value of H (work days lost). 
The total annual monetary gain from reduced air pollution to all the citizens of Kanpur city (due to the gain in workdays and reduced mitigating expenditures) is Rs 212.82 million. This estimate forms a lower bound of potential benefits from reduced air pollution in Kanpur. The benefits could be much higher if household expenditures on averting activities, monetary value of discomfort and utility losses could also be taken into account.

\section{Conclusions and Policy Implications}

The study undertaken and the analysis presented in this paper offers conclusive evidence of the significant economic gains deducible from reduction in air pollution even as such reductions continue to impact positively on the health status of the populace. The results clearly show that the annual welfare gains to a working individual from reduced air pollution are Rs 130.39 due to reduction in workdays lost and due to the reduced medical expenditures is Rs 34.43 to a person. This, constitute a total gain of Rs 212.82 million per annum to the population of the city of Kanpur.

These findings are in line with earlier studies as shown below:

- The per annum reduction in number of workdays lost due to the reduced air pollution is estimated as 0.41 in Kolkata, 0.75 in Delhi, 0.82 in Taiwan (Alberini \& Krupnick, 2000), and 0.63 in Kanpur;

- The per annum reduction in the average number of days of medicine is 1.88 in Kanpur as compared to 1.3 in Taiwan;

- The estimated annual gain to a working individual for Kolkata and Delhi is estimated as Rs 206.57 and Rs 381.46 respectively (Murty, et al., 2003) whereas in Kanpur it is Rs 164.82 .

However, these estimates do not include expenditures on averting activities and the opportunity cost of time associated with medical care (the time spent on traveling and waiting at doctor's clinic and the time of the attendant or accompanying person, etc.). Also the estimates are lower bound estimates because the household health production function model does not take into consideration losses that are incurred due to reduced efficiency and the discomfort caused by illness. Economic gains could also be higher as a result of improved visibility, recreation opportunities and reduction in material damages.

Kanpur is a city that needs to act now to reduce air pollution. However, there are significant costs involved in any attempt to improve air quality. This would be the case of CNG is introduced for vehicular transportation or if the mode of transport is changed from road to metro rail or if any relocation of polluting industries occurs. The estimates of benefits or welfare gains from air pollution reduction obtained in this paper should help justify these costs. 


\section{Acknowledgements}

This work was undertaken with the financial support of the South Asian Network for Development and Environmental Economics (SANDEE). I have gained enormously from the comments of resource persons Jeff Vincent, Maureen Cropper, Priya Shyamsunder, M N Murty and many other resource persons of SANDEE at various stages of this study. I am thankful to Dr. Madheswaran for giving me valuable econometric suggestions and two anonymous referees for very useful comments on earlier drafts of this report. I wish to express my thanks to the SANDEE Secretariat for the encouragement and support for doing this work. 


\section{References}

Alberini, A, M Cropper, et al., (1997), "Valuing Health Effects of Air pollution in Developing Countries: the Taiwan Experience," Journal of Environmental Economics and Management, (34): 107-26.

Alberini, A and A Krupnick (1997), "Air Pollution and Acute Respiratory Illness: Evidence from Taiwan and Los Angeles," American Journal Agriculture Economics, (79. 7): 1620-1624.

Alberini, A and A Krupnick (2000), "Cost of Illness and Willingness to Pay Estimates of the Benefits of Improved Air Quality: Evidence from Taiwan," Land Economics, (76): 37-53.

Amemiya, Takeshi (1984), “Tobit Models: A Survey," Journal of Econometrics, (24): $3-6$.

Avol, E L, et al., (2001), "Respiratory effects of relocating to areas of differing air Pollution levels," American Journal of Respiratory Critical Care Medicine, (164): 2067-2072.

Banerjee, S (2001), "Economic Valuation of Environmental Benefits and Costs," in Rabindra N. Bhattacharya (ed), Environmental Economics An Indian Perspective, New Delhi: Oxford University Press, pp. 125 -159.

Bresnahan, B W, M Dickie, and S Gerking (1997), "Averting Behaviour and Urban Air Pollution," Land Economics, (73): 340-357.

California Environmental Protection Agency (CEAP) 2004, “Fact Sheet 2004-01-00

Health Effects of Particulate Matter," http://www.arb.ca.gov/research/health/fs/PM03fs.pdf.

Cameron, A Colin (1986), "Econometric Models Based On Count Data: Comparisons and Applications of Some Estimators and Tests," Journal of Applied Econometrics, Vol. 1, (29-53)

Cameron, A Colin and Trivedi, P.K. (1998), Regression Analysis of Count Data, Cambridge University Press.

CMIE (2000), Profiles of Districts, Centre for monitoring Indian Economy Private Limited, Mumbai.

Committee on the Medical Effects of Air Pollutants (COMEAP) (1998), "The Quantification of the Effects of Air Pollution on Health in the United Kingdom," (http/ /www.doh.gov.uk.html). 
Cropper, Maureen, Nathalie B Simon, A Alberini, Seema Arora, and P K Sharma (1997), "The Health Benefits of Air Pollution Control in Delhi," American Journal of Economics, (79.No.5): 1625-1629.

Cropper, Maureen L (1981), "Measuring the Benefits from Reduced Morbidity," American Economic Review, (71): 235-240.

Dasgupta, Purnamita (2001), "Valuing Health Damages from Water Pollution in Urban Delhi: A Health Production Function Approach," Working Paper No. E/210/2001, Institute of Economic Growth, Delhi.

Dickie, M and S Gerking (1991), "Willingness to Pay for Ozone Control: Inferences from the Demand for Medical Care," Journal of Environmental Economics and Management, (21): 1-16.

M.El-Fadel and M Masood (2000), "Particulate Matter in Urban Areas: Health-based Economic Assessment," The Science of the Total Environment, (257): 133-146.

Eskeland, G S (1997), "Air Pollution Requires Multipollutant Analysis: The Case of Santiago, Chile," American Journal of Agricultural Economics, (79.5): 1636-1641.

Freeman, A. M. III (1993), "The Measurement of Environmental and Resource Values: Theory and Methods”. Resources for the Future: Washington, D. C.

Faiz, Asif, et el., (1996),"Air Pollution from Motor Vehicles: Standards and Technologies for Controlling Emissions," World Bank and United Nations Environment Programme, Washington, D.C.

Gerking, S and Linda R Stanley (1986), “An Economic Analysis of Air Pollution and Health: The Case of St Louis," Review of Economics and Statistics, (68): 115-121.

Gauderman, W J, et al., (2002), "Association between Air Pollution and Lung Function Growth in Southern California Children: Results from a Second Cohort," American Journal of Respiratory Critical Care Medicine, (166.1): 74-84.

Grossman, M (1972), "On the Concept of Health Capital and the Demand for Health," Journal of Political Economy, (80): 223-255.

Hausman, J, B.H.Hall and Z.Griliches (1984), "Econometric Models For Count Data with an Application to the Patents R \&D Relationship," Econometrica, (52.July): 701-720.

Harrington, W and Paul R Portney (1987), "Valuing the Benefits of Health and Safety Regulations," Journal of Urban Economics, (22): 101-112.

Kolstad, Charles D (2000), Environmental Economics, New York USA: Oxford University Press. 
Kumar, S and D N Rao (2001), "Valuing Benefits of Air Pollution Abatement Using Health Production Function: A Case study of Panipat Thermal Power Station, India," Journal of Environmental \& Resource Economics, (20): 91-102

Murty, M N, A J James and Smita Misra (1999), Economics of Water Pollution: The Indian Experience, New Delhi: Oxford University Press.

Murty, M N, S C Gulati and A Banerjee (2003), "Health Benefits from Urban Air Pollution Abatement in the Indian Subcontinent," Discussion Paper no. 62/2003, Delhi: Institute of Economic Growth, IEG Website.

Murty, M N and Surender Kumar (2003), Environmental and Economic Accounting for Industry, New Delhi: Oxford University Press.

Oates, Wallace E and Maureen Cropper (1992), "Environmental Economics: A Survey," Journal of Economic Literature, (30): 675-740.

Onursal, Bakir and P Gautam Sushid (1997), "Vehicular Air Pollution Experience from Several Latin American Urban Centres," World Bank Technical Paper No.737, Washington, DC: The World Bank.

Ostro, B et al., (1995), "Air Pollution and Mortality: Results from Santiago, Chile," Policy Research Department, Working Paper 1453, Washington, D C: World Bank.

Parikh, K and J Parikh (1997), Accounting and Valuation of Environment, vols. I \& II, ESCAP.

Roger Perman, et al., (1996), Natural Resources and Environmental Economics, London: Longman

Pope III, C A, et al.,(1992), "Daily Mortality and PM-10 Pollution in Utah Valley," Archives of Environmental Health, (42.3): 211-17.

Pope III, C A, et al., (2002), "Lung cancer, cardiopulmonary mortality, and long-term exposure to fine particulate air pollution," Journal of the American Medical Association, (287): 1123-1141.

Smith, V Kerry (1993), "Non-Market Valuation of Environmental Resources: An Interpretive Appraisal," Land Economics, 69 (1): 1-26.

Varadarajan, D B and V Subramanian (1993), Air Pollution and Road Transport, New Delhi: Ashish Publishing House. 


\section{Tables}

Table 1: Estimated Loads of Pollutants of Different Vehicles in Kanpur (Figures in percentages)

\begin{tabular}{|l|l|l|l|l|l|}
\hline \multirow{2}{*}{ Vehicle Type } & \multirow{2}{*}{$\begin{array}{c}\text { Veh- kms } \\
\text { (In Lakhs) }\end{array}$} & \multicolumn{4}{|c|}{ Pollution Loads in Tons Per Day } \\
\cline { 3 - 6 } & & \multicolumn{1}{|c|}{ CO } & \multicolumn{1}{|c|}{ NO $_{\mathbf{x}}$} & \multicolumn{1}{|c|}{ HC } & \multicolumn{1}{|c|}{ PM } \\
\hline Cars + Taxis & 16.34 & 10.45 & 10.69 & 4.9 & 6.70 \\
\hline Two Wheelers & 60.42 & 55.54 & 6.44 & 83.97 & 25.03 \\
\hline Auto Diesel & 12.56 & 20.71 & 27.82 & 0.22 & 26.46 \\
\hline Auto Petrol & 1.04 & 2.65 & 0.09 & 4.43 & 0.84 \\
\hline Goods Inter City & 4.52 & 6.92 & 30.46 & 3.09 & 23.35 \\
\hline City Bus & 0.66 & 0.5 & 6.57 & 0.35 & 4.14 \\
\hline Inter City Bus & 0.85 & 0.76 & 9.72 & 0.56 & 7 \\
\hline Goods Local & 3.61 & 2.47 & 8.2 & 0.79 & 6.47 \\
\hline \multicolumn{1}{|c|}{ Total } & 48.18 & 28.73 & 7.25 & 11.70 & 1.91 \\
\hline
\end{tabular}

Source: Centre for Road Research Institute (CRRI)

Note: Vehicular pollution load is estimated on the basis of vehicle-kilometer traveled by different vehicle types and the fuel used. The total daily pollution load of $\mathrm{CO}, \mathrm{NO}_{\mathrm{x}}, \mathrm{HC}$ and $\mathrm{PM}$ from traffic is estimated as $28.73,7.25,11.7$, and 1.91 tons respectively by CRRI using the Central Pollution Control Board's (CPCB) numbers on emission pollution loads and deterioration factors. The deterioration factors take into consideration age-wise distribution of vehicles in the city.

Table 2: Point Source Emissions in (kg. / hr.)

\begin{tabular}{|l|r|r|c|}
\hline \multicolumn{1}{|c|}{ Source } & $\mathrm{SO}_{2}$ & $\mathrm{NO}_{\mathrm{x}}$ & $\mathrm{SPM}$ \\
\hline Fazal Ganj Industrial Area & 71 & 28 & 585 \\
\hline Dada Nagar Industrial Area & 134 & 101 & 180 \\
\hline Panki Industrial Area & 254 & 112 & 2600 \\
\hline Jajmau Industrial Area & 55 & 50 & 607 \\
\hline Industrial Estate & 21 & 9 & 195 \\
\hline Fertilizer Unit & 91 & 62 & 162 \\
\hline Power Plant, Panki & 1090 & 751 & 3900 \\
\hline Textile Mills & 63 & 44 & 682 \\
\hline Lalimli & 5 & 6 & 97 \\
\hline Sarvodaya Nagar Industrial Area & 3 & 2 & 65 \\
\hline
\end{tabular}

Source: CPCB 
Table 3: Emissions from Domestic Fuels

\begin{tabular}{|l|l|l|l|l|l|l|}
\hline Sources & \multicolumn{3}{l|}{ E mission Rate (kg/day) } \\
\hline Type of fuel & Consumption/day & PM & So 2 & N 0x & C O \\
\hline Coal (Tons) & 70 & 350 & 532.00 & 104 & 3132 \\
\hline Kerosene (KL) & 105 & 213 & 357.00 & 163 & 21 \\
\hline L PG (Tons) & 91 & 38 & 0.04 & 164 & 40 \\
\hline W ood \& related fuel (tons) & 30 & 205 & 15.00 & 150 & 30 \\
\hline
\end{tabular}

Source: CPCB-News Letter Parivesh, (2000)

Table 4: Source Distribution of $\mathrm{PM}_{10}(\mathrm{RSPM})$ in Various Areas of Kanpur

\begin{tabular}{|l|c|c|c|c|}
\hline \multirow{2}{*}{ Sources } & \multicolumn{4}{|c|}{ Percentage of PM $_{10}(\mathrm{RSPM})$ contrtibuted in various } \\
\cline { 2 - 5 } & Industrial & Commercial & Residential & Kerb \\
\hline Auto exhaust & - & - & - & 16 \\
\hline Auto exhaust and diesel generating sets & 32 & 22 & 39 & - \\
\hline Re-suspended dust & 24 & 30 & 20 & 31 \\
\hline Secondary aerosol formation & 12 & 8 & - & 10 \\
\hline Earth crust & - & - & 6 & 14 \\
\hline Small scale industries & 8 & 16 & 12 & - \\
\hline Other sources & 24 & 24 & 23 & 29 \\
\hline
\end{tabular}

Source: Auto Fuel Policy Report (2002)

Table 5: Distribution of Households in the Sample

\begin{tabular}{|c|c|c|c|c|c|c|}
\hline \multicolumn{6}{|c|}{ Number of Rooms } & Total \\
\hline Stations & kaccha house $(0)$ & 1 & 2 & 3 & $4+$ & \\
\hline $\mathrm{FG}$ & 17 & 82 & 29 & 21 & 6 & 155 \\
\hline DKP & 58 & 37 & 36 & 9 & 10 & 150 \\
\hline $\mathrm{VN}$ & 49 & 51 & 25 & 10 & 15 & 150 \\
\hline KN & 39 & 52 & 26 & 17 & 16 & 150 \\
\hline Total & 163 & 222 & 116 & 57 & 47 & 605 \\
\hline $\begin{array}{c}\% \\
\text { Sample }\end{array}$ & 26.9 & 36.7 & 19.2 & 9.4 & 7.8 & 100 \\
\hline$\% \mathrm{KDA}$ & $67(0+$ & & 21 & 6 & 6 & 100 \\
\hline
\end{tabular}


Table 6: Summary Information for the Household Survey

\begin{tabular}{|l|c|c|c|c|}
\hline Variables & Mean & Std. Dev. & Minimum & Maximum \\
\hline Family Data & & & & \\
\hline Number of rooms & 1.40 & 1.39 & 0 & 9 \\
\hline $\begin{array}{l}\text { Religion: Hindu=1, Non- } \\
\text { Hindu=0 }\end{array}$ & 0.902 & 0.297 & 0 & 1 \\
\hline $\begin{array}{l}\text { Family Background: } \\
\text { Urban=1, Rural=0 }\end{array}$ & 0.94 & 0.237 & 0 & 1 \\
\hline Family Size & 5.16 & 1.949 & 1 & 11 \\
\hline Earning Members & 1.426 & 0.785 & 0 & 6 \\
\hline Annual income & 78505 & 86654 & 10000 & 800000 \\
\hline Coal burning & 0.288 & 0.453 & 0 & 1 \\
\hline Indoor plant & 0.321 & 0.467 & 0 & 1 \\
\hline Number of Married & 2.385 & 1.102 & 0 & 11 \\
\hline Individual Data & & & & 1 \\
\hline Number of Adults & 0.633 & 0.483 & 0 & 1 \\
\hline Age & 26.60 & 17.78 & 0.25 & 100 \\
\hline Education & 6.3 & 5.57 & 0 & 23 \\
\hline Chronic Disease & 0.102 & 0.302 & 0 & 1 \\
\hline Smoking & 0.180 & 0.385 & 0 & 1 \\
\hline Drinking & 0.062 & 0.241 & 0 & 1 \\
\hline Walk morning/evening & 0.080 & 0.272 & 0 & 1 \\
\hline Exercise & 0.039 & 0.193 & 0 & 1 \\
\hline
\end{tabular}

Table 7: Descriptive Statistics of Variables Used in Estimation

\begin{tabular}{|l|l|l|l|l|}
\hline Variables & \multicolumn{1}{|c|}{ Mean } & \multicolumn{1}{c|}{ S.D } & \multicolumn{1}{c|}{ Minimum } & Maximum \\
\hline $\mathrm{H}($ workdays lost $)$ & .0267 & .3328 & 0 & 7 \\
\hline $\mathrm{M}(\mathrm{Rs})$ & 3.62 & 25.41 & 0 & 1200 \\
\hline $\mathrm{Rspm}\left(\mu \mathrm{g} / \mathrm{m}^{3}\right)$ & 225.68 & 73.85 & 42.5 & 462.5 \\
\hline Dtemp $\left(^{0} \mathrm{C}\right)$ & 9.87 & 3.21 & 5.2 & 15.27 \\
\hline Tmax $\left({ }^{0} \mathrm{C}\right)$ & 30.51 & 8.58 & 15.49 & 42.9 \\
\hline $\mathrm{Nox}\left(\mu \mathrm{g} / \mathrm{m}^{3}\right)$ & 23.28 & 5.17 & 10.5 & 39 \\
\hline $\mathrm{So}_{2}\left(\mu \mathrm{g} / \mathrm{m}^{3}\right)$ & 9.81 & 4.18 & 4 & 21.67 \\
\hline Wind $(\mathrm{m} / \mathrm{sec})$ & 7.39 & 2.72 & 3.54 & 14.66 \\
\hline Rhmin $(\%)$ & 66.10 & 17.54 & 30.1 & 87.7 \\
\hline Age $($ years $)$ & 36.40 & 12.18 & 12 & 85 \\
\hline Bcj & .6770 & .4677 & 0 & 1 \\
\hline Asthma & .0198 & .1392 & 0 & 1 \\
\hline Bp & .0247 & .1552 & 0 & 1 \\
\hline Tb & .0193 & .1378 & 0 & 1 \\
\hline Heart & .0148 & .1208 & 0 & 1 \\
\hline Total Observations & & & & \\
\hline
\end{tabular}


Table 8: Poisson Equations of Workdays Lost (H)

\begin{tabular}{|c|c|}
\hline Independent Variables & Coefficients (re) \\
\hline RSPM (+) & $0.0027 \quad(3.16)^{* * *}$ \\
\hline DTEMP & $-0.0545(2.00)^{* *}$ \\
\hline TMAX & $-0.0844 \quad(7.16)^{* * *}$ \\
\hline $\mathrm{NO}_{\mathrm{x}}(+)$ & $0.0153 \quad(1.29)$ \\
\hline $\mathrm{SO}_{2} \quad(+)$ & $\begin{array}{ll}0.0353 \quad(1.60) \\
\end{array}$ \\
\hline WIND (-) & $\begin{array}{ll}-0.0325 & (0.99)\end{array}$ \\
\hline RHMIN & $-0.0312(5.07)^{* * *}$ \\
\hline $\mathrm{AGE}$ & $0.2530 \quad(3.53) * * *$ \\
\hline $\mathrm{AGE}^{2}$ & $-0.0029 \quad(3.36)^{* * *}$ \\
\hline $\mathrm{BCJ}$ & $0.2426 \quad(0.71)$ \\
\hline ASTHMA & $3.5390 \quad(2.20)^{* *}$ \\
\hline $\mathrm{BP}$ & $-1.2865 \quad(0.87)$ \\
\hline TB & $1.1624 \quad(1.13)$ \\
\hline HEART & $1.5492 \quad(0.89)$ \\
\hline Constant & $-5.0748 \quad(3.05)^{* * *}$ \\
\hline lnalpha & 2.737 SE (0.1409) \\
\hline Alpha & 15.44 SE (2.1761) \\
\hline LR test of alpha $=0$ & $\begin{array}{l}\text { Chibar2 }(01)=1002.81 \text { Prob. }>=\text { chibar2 } \\
=0.00\end{array}$ \\
\hline Log likelihood & -1401.66 \\
\hline Wald chi2 (7) \& (14) & 154.15 \\
\hline Number of observations & 14580 \\
\hline Number of groups & 815 \\
\hline
\end{tabular}

Notes: Figures in parentheses are t values. The Hausman test does not reject the random effects. ***Significant at $1 \%$ level; **Significant at $5 \%$ level; *Significant at $10 \%$ level.

Hausman test does not reject the random effects. 
Table 9: Tobit Equations of Mitigating Activities (M) Left Censored (0)

\begin{tabular}{|c|c|c|}
\hline Independent Variables & Equation (1) & Marginal Effect \\
\hline RSPM (+) & $0.0912 \quad(1.42)$ & 0.0040 \\
\hline DTEMP & $\begin{array}{ll}-6.553 & (3.49)^{* * *}\end{array}$ & -0.286 \\
\hline TMAX & $-0.1329 \quad(0.17)$ & -0.0058 \\
\hline $\mathrm{NO}_{\mathrm{x}}$ & $2.878 \quad(3.38)^{* * *}$ & 0.126 \\
\hline $\mathrm{SO}_{2}$ & $\begin{array}{ll}0.8724 \quad(0.82) \\
\end{array}$ & 0.0381 \\
\hline WIND & $\begin{array}{ll}-6.228 & (2.95)^{* * *}\end{array}$ & -0.272 \\
\hline RHMIN & $-0.4608 \quad(1.07)$ & -0.020 \\
\hline $\mathrm{AGE}$ & $\begin{array}{ll}6.475 & (3.73)^{* * *}\end{array}$ & 0.283 \\
\hline $\mathrm{AGE}^{2}$ & $-0.0703 \quad(3.31)^{* * *}$ & -0.0031 \\
\hline$\overline{\mathrm{BCJ}}$ & $46.16 \quad(5.12)^{* * *}$ & 2.0168 \\
\hline ASTHMA & $\begin{array}{ll}79.43 & (3.57)^{* * *}\end{array}$ & 3.470 \\
\hline $\mathrm{BP}$ & $74.04 \quad(3.63) * * *$ & 3.235 \\
\hline $\mathrm{TB}$ & $\begin{array}{ll}62.76 & (2.80)^{* * * *}\end{array}$ & 2.742 \\
\hline HEART & $\begin{array}{ll}79.88 & (3.29)^{* * *}\end{array}$ & 3.790 \\
\hline Constant & $-481.7 \quad(6.66) * * *$ & -21.045 \\
\hline Log Likelihood & \multicolumn{2}{|c|}{-6018.9} \\
\hline Wald chi 2 (14): & \multicolumn{2}{|c|}{$115.3 * * *$} \\
\hline Uncensored Obs: 637 & \multicolumn{2}{|c|}{ Left censored Obs: 13943} \\
\hline Number of groups: 815 & \multicolumn{2}{|l|}{ Obs Per Group: 6 to 18} \\
\hline
\end{tabular}

Notes: Figures in parentheses are t values.

$* * *$ Significant at $1 \%$ level; ** Significant at $5 \%$ level; *** Significant at $1 \%$ level. 


\section{Figures}

Figure 1: Air Pollution in Different Cities in India

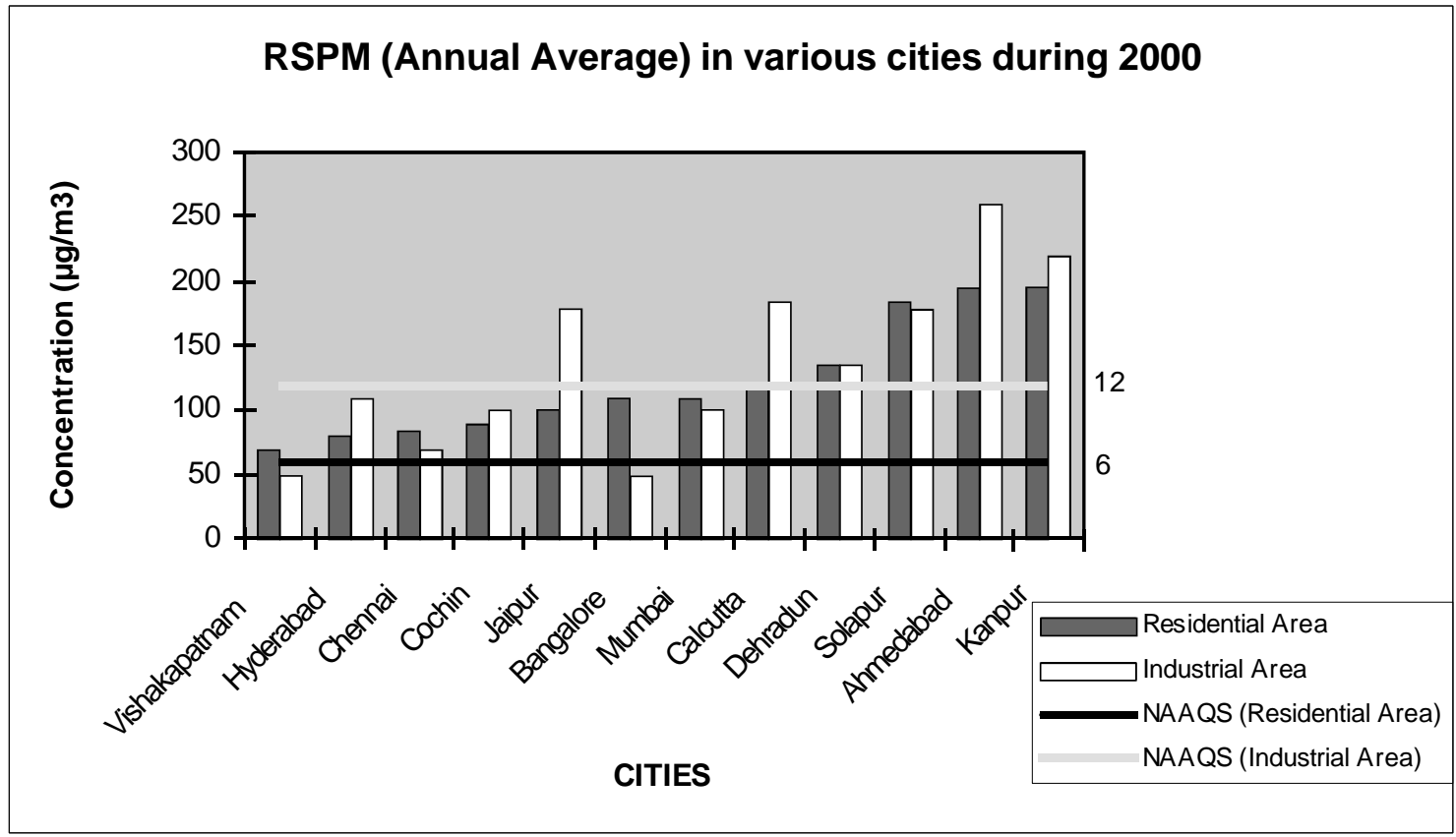

Source: Central Pollution Control Board (CPCB)

Figure 2: Air Quality in Kanpur

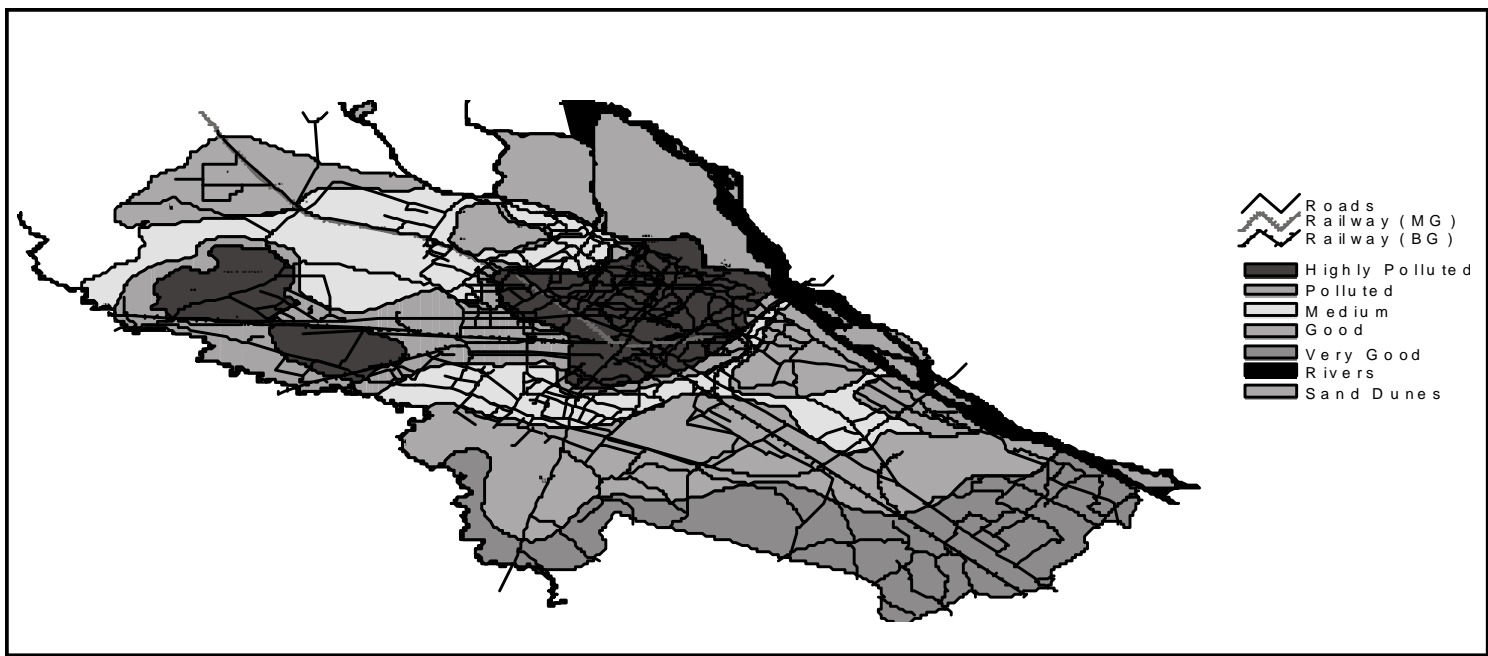


Figure 3: Weekly Average of RSPM (mg/m3) for the Stated 18 Weeks

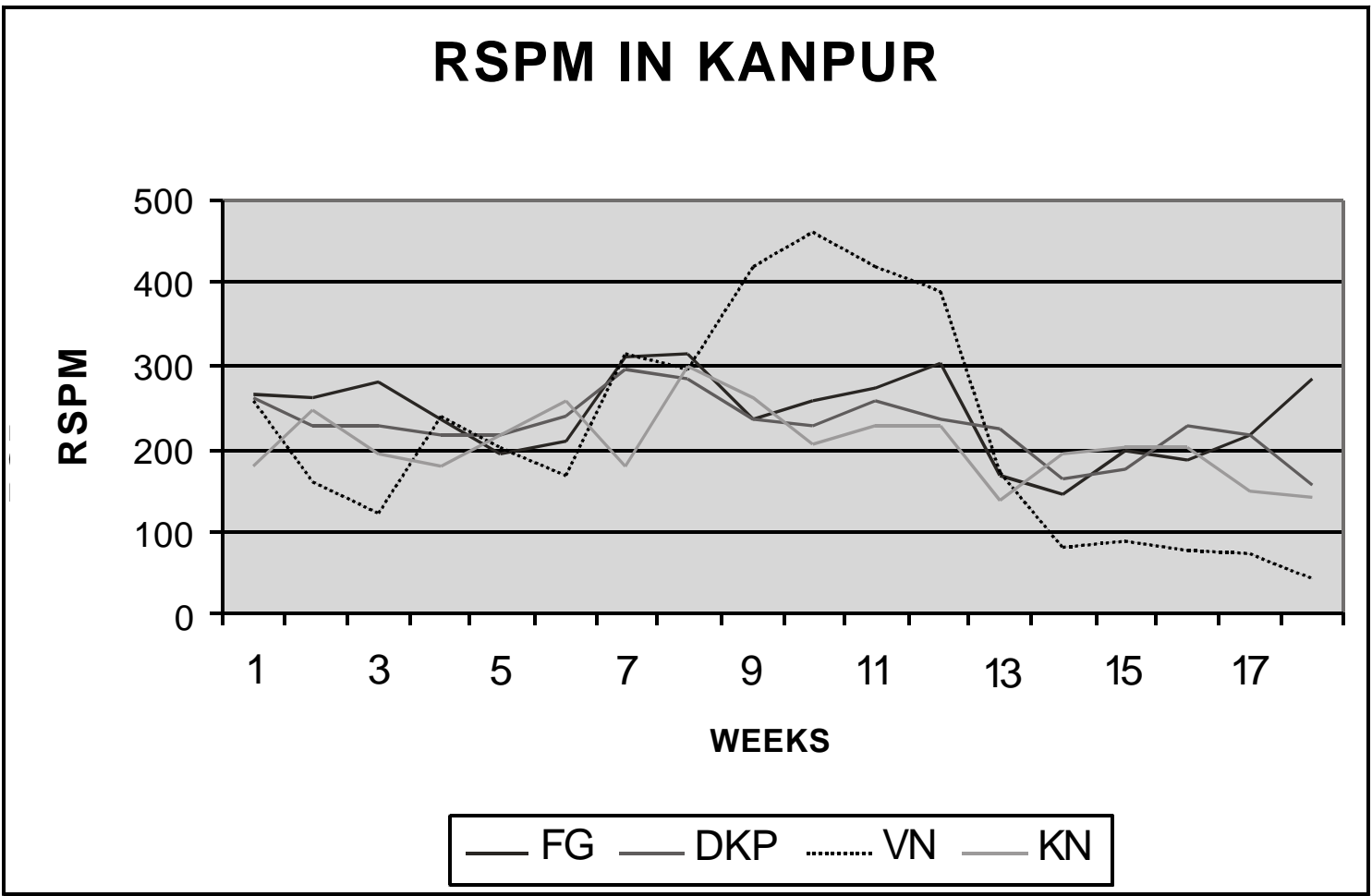

Note: The first 6 weeks correspond to winter, followed by the 6 weeks of summer and the 6 weeks of monsoon periods in Kanpur. Fazal Ganj (FG) is an industrial area whereas Deputy Ka Parao (DKP), Vikas Nagar (VN) and Kidwai Nagar (KN) are residential areas. 


\section{Appendix A}

\section{Negative Binomial Model:}

The negative binomial regression is used to estimate count models when the Poisson estimation shows over dispersion, which usually exists in primary data. The negative binomial estimate takes into consideration an ancillary parameter á that is an estimate of degree of over dispersion.

When a is zero, negative binomial has the same distribution as Poisson. The larger a is the greater the amount of over dispersion in the data.

The negative binomial distribution is given as:

$\operatorname{Pr}[y / x]=\frac{\Gamma\left(y+\alpha^{-1}\right)}{y ! \Gamma\left(\alpha^{-1}\right)}\left(\frac{\alpha^{-1}}{\alpha^{-1}+\lambda}\right)^{\alpha-1}\left(\frac{\lambda}{\alpha^{-1}+\lambda}\right)^{y}$

In the context of count regression models, the negative binomial distribution can be thought of as a Poisson distribution with unobserved heterogeneity. The generalized Poisson model is given as

$\ln \mu_{\mathrm{it}}=\beta_{1 \mathrm{i}}+\beta_{2} \mathrm{X}_{2 \mathrm{it}}+\beta_{3} \mathrm{X}_{3 \mathrm{it}}+\longleftarrow+\beta_{\mathrm{S}} \mathrm{X}_{\mathrm{Sit}}+\varepsilon_{\mathrm{I}}$

where $\varepsilon_{\mathrm{I}}$ reflects either the cross-sectional heterogeneity or the specification error in the regression model. The variance of negative binomial (NB1) is equal to mean + amean $^{2}$, where $a>=0$ is a dispersion parameter. The maximum likelihood method is used to estimate a as well as the parameter of the regression model for $\ln (\mu)$. 
Table 10: Negative Binomial Equation of Workdays Lost $(\mathrm{H})$

\begin{tabular}{|c|c|c|}
\hline Independent Variable & Coefficients (fe) & Coefficients (re) \\
\hline RSPM (+) & $0.0017 \quad(1.28)$ & $0.0011 \quad(0.77)$ \\
\hline DTEMP & $\begin{array}{ll}-0.0352 \quad(0.77) \\
\end{array}$ & $\begin{array}{ll}-0.0641 \quad(1.49) \\
\end{array}$ \\
\hline TMAX & 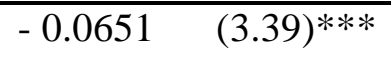 & $-0.0522 \quad(2.87)^{* *}$ \\
\hline $\begin{array}{ll}\mathrm{NO}_{\mathrm{x}} & (+)\end{array}$ & $0.0089 \quad(0.48)$ & $0.0338 \quad(1.80)^{*}$ \\
\hline $\begin{array}{ll}\mathrm{SO}_{2} & (+)\end{array}$ & $0.0417 \quad(1.22)$ & $-0.0334 \quad(1.25)$ \\
\hline WIND (-) & $\begin{array}{ll}-0.0345 \quad(0.64) \\
\end{array}$ & $\begin{array}{ll}-0.0498 \quad(0.93)\end{array}$ \\
\hline RHMIN & $-0.0193 \quad(1.92)^{*}$ & $-0.0185(1.86)^{*}$ \\
\hline AGE & & $0.1842 \quad(3.22)^{* * *}$ \\
\hline $\mathrm{AGE}^{2}$ & & $-0.0021 \quad(3.00)^{* * *}$ \\
\hline BCJ & & $0.2665 \quad(1.14)$ \\
\hline ASTHMA & & $1.565 \quad(3.61)^{* * *}$ \\
\hline $\mathrm{BP}$ & & $-0.5109 \quad(0.72)$ \\
\hline TB & & $0.5946 \quad(1.12)$ \\
\hline HEART & & $0.7308 \quad(1.08)$ \\
\hline Constant & $\begin{array}{ll}-1.0745 \quad(0.82) \\
\end{array}$ & $-5.1424(2.93)^{* * *}$ \\
\hline Log likelihood & -456.00 & -972.422 \\
\hline Wald chi2 (7) \& (14) & 31.61 & 57.80 \\
\hline $\ln \_r$ & & $\begin{array}{lll}-0.0787 & \text { SE } & (0.1619)\end{array}$ \\
\hline ln_s & & $-0.8550 \quad$ SE $\quad(0.4123)$ \\
\hline $\mathrm{R}$ & & $0.9244 \quad$ SE $\quad(0.1497)$ \\
\hline S & & $0.4253 \quad \mathrm{SE} \quad(0.1753)$ \\
\hline
\end{tabular}

Notes: Likelihood - ratio test vs. pooled: chibar2 $(01)=9.18$ prob. $>=$ chibar $2=0.001$

Number of observations $=14580$;

Number of groups $=815$

Notes: Figures in parentheses are $\mathrm{t}$ values. The LR test rejects random effects.

***Significant at $1 \%$ level; **Significant at $5 \%$ level; *Significant at $10 \%$ level.

The due to the assumption of equality of mean and variance in Poisson distribution the t-values are over inflated in such a situation negative binomial is a better method of estimation which, accounts for over dispersion and produces accurate $t-$ values. Household health production function [Table 10] shows that the coefficient of RSPM is positive, showing an increase in loss of workdays due to air pollution induced illnesses. One unit increase in the level of RSPM increases the expected number of workdays 
lost by 0.17 percent $[100 * 0.0017=0.17$ percent $]$. Similarly, one unit increase in $\mathrm{NO}_{x}$ and $\mathrm{SO}_{2}$ levels increases the expected number of workdays lost by 0.89 percent and 4.17 percent respectively even though both the pollution parameters $\left(\mathrm{NO}_{\mathrm{x}}\right.$ and $\mathrm{SO}_{2}$ ) are within permissible limits (Table 1-summary statistics) in the urban city of Kanpur.

The coefficient of maximum temperature (TMAX) is negative and significant at 1 percent level of significance suggesting that the workdays lost due to air pollution related illnesses are higher during colder days. The negative coefficient of DTEMP (variation in temperature) also indicates a reduction in workdays lost on clear days (sunny days). Similarly, dry weather (minimum relative humidity, RHMIN) decreases the expected number of workdays lost. 


\section{Appendix B}

\section{National Ambient Air Quality Standards:}

The national standards for ambient air quality were laid down and notified by CPCB in 1994, under section 16 (2) (h) of the Air (Prevention and Control of Pollution) Act, 1981, and the Environment (Protection) Act, 1986.

\section{National Ambient Air Quality Standards (NAAQS)}

\begin{tabular}{|c|c|c|c|c|}
\hline \multirow[t]{2}{*}{ Pollutants } & \multirow{2}{*}{$\begin{array}{l}\text { Time-weighted } \\
\text { average }\end{array}$} & \multicolumn{3}{|c|}{$\underline{\text { Concentration in ambient air }}$} \\
\hline & & $\begin{array}{l}\text { Industrial } \\
\text { Areas }\end{array}$ & $\begin{array}{l}\text { Residential, } \\
\text { Rural \& } \\
\text { Other Areas }\end{array}$ & $\begin{array}{c}\text { Sensitive } \\
\text { Areas }\end{array}$ \\
\hline \multirow{2}{*}{ Sulphur Dioxide $\left(\mathrm{SO}_{2}\right)$} & Annual Average* & $80 \mu \mathrm{g} / \mathrm{m}^{3}$ & $60 \mu \mathrm{g} / \mathrm{m}^{3}$ & $15 \mu \mathrm{g} / \mathrm{m}^{3}$ \\
\hline & 24 hours $* *$ & $120 \mu \mathrm{g} / \mathrm{m}^{3}$ & $80 \mu \mathrm{g} / \mathrm{m}^{3}$ & $30 \mu \mathrm{g} / \mathrm{m}^{3}$ \\
\hline \multirow{2}{*}{$\begin{array}{c}\text { Oxides } \\
\text { ofNitrogen as(NOx) }\end{array}$} & Annual Average* & $80 \mu \mathrm{g} / \mathrm{m}^{3}$ & $60 \mu \mathrm{g} / \mathrm{m}^{3}$ & $15 \mu \mathrm{g} / \mathrm{m}^{3}$ \\
\hline & 24 hours $* *$ & $120 \mu \mathrm{g} / \mathrm{m}^{3}$ & $80 \mu \mathrm{g} / \mathrm{m}^{3}$ & $30 \mu \mathrm{g} / \mathrm{m}^{3}$ \\
\hline \multirow{2}{*}{$\begin{array}{c}\text { Suspended Particulate } \\
\text { Matter (SPM) }\end{array}$} & Annual Average* & $360 \mu \mathrm{g} / \mathrm{m}^{3}$ & $140 \mu \mathrm{g} / \mathrm{m}^{3}$ & $70 \mu \mathrm{g} / \mathrm{m}^{3}$ \\
\hline & 24 hours $* *$ & $500 \mu \mathrm{g} / \mathrm{m}^{3}$ & $200 \mu \mathrm{g} / \mathrm{m}^{3}$ & $100 \mu \mathrm{g} / \mathrm{m}^{3}$ \\
\hline \multirow{2}{*}{$\begin{array}{c}\text { Respirable Particulate } \\
\text { Matter (RPM) } \\
\text { (size less than } 10 \text { microns) }\end{array}$} & Annual Average* & $120 \mu \mathrm{g} / \mathrm{m}^{3}$ & $60 \mu \mathrm{g} / \mathrm{m}^{3}$ & $50 \mu \mathrm{g} / \mathrm{m}^{3}$ \\
\hline & 24 hours $* *$ & $150 \mu \mathrm{g} / \mathrm{m}^{3}$ & $100 \mu \mathrm{g} / \mathrm{m}^{3}$ & $75 \mu \mathrm{g} / \mathrm{m}^{3}$ \\
\hline \multirow[t]{2}{*}{ Lead $(\mathrm{Pb})$} & Annual Average* & $1.0 \mu \mathrm{g} / \mathrm{m}^{3}$ & $0.75 \mu \mathrm{g} / \mathrm{m}^{3}$ & $0.50 \mu \mathrm{g} / \mathrm{m}^{3}$ \\
\hline & 24 hours $* *$ & $1.5 \mu \mathrm{g} / \mathrm{m}^{3}$ & $1.00 \mu \mathrm{g} / \mathrm{m}^{3}$ & $0.75 \mu \mathrm{g} / \mathrm{m}^{3}$ \\
\hline \multirow[t]{2}{*}{ Ammonia1 } & Annual Average* & $0.1 \mathrm{mg} / \mathrm{m}^{3}$ & $0.1 \mathrm{mg} / \mathrm{m}^{3}$ & $0.1 \mathrm{mg} / \mathrm{m}^{3}$ \\
\hline & 24 hours $* *$ & $0.4 \mathrm{mg} / \mathrm{m}^{3}$ & $0.4 \mathrm{mg} / \mathrm{m}^{3}$ & $0.4 \mathrm{mg} / \mathrm{m}^{3}$ \\
\hline \multirow[t]{2}{*}{ Carbon Monoxide (CO) } & 8 hours $* *$ & $5.0 \mathrm{mg} / \mathrm{m}^{3}$ & $2.0 \mathrm{mg} / \mathrm{m}^{3}$ & $1.0 \mathrm{mg} / \mathrm{m}^{3}$ \\
\hline & 1 hour & $10.0 \mathrm{mg} / \mathrm{m}^{3}$ & $4.0 \mathrm{mg} / \mathrm{m}^{3}$ & $2.0 \mathrm{mg} / \mathrm{m}^{3}$ \\
\hline
\end{tabular}

* Annual arithmetic mean of minimum 104 measurements in a year, taken twice a week, 24 hourly at a uniform interval.

** 24 / 8 hourly values should be met $98 \%$ of the time in a year. However, $2 \%$ of the time, it may exceed but not on two consecutive days. 


\section{Appendix C}

\section{Questionnaire for the household survey}

Section 1: Survey Information

S. No.

Date of Entry:

Air Pollution Monitoring station:

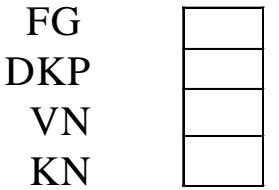

Enumerator' Name:

Respondent's

Name: Mr./ Mrs./ Miss

Address:

Pin code:

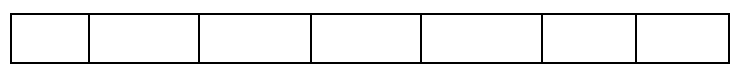

Telephone No.

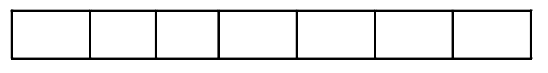

Mobile No.

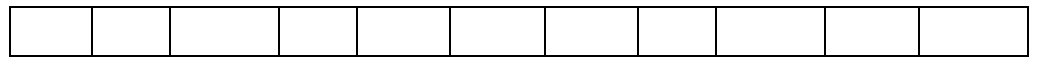

Section 2: Socio-economic characteristics:

\subsection{Household}

a) Accommodation: Number of Rooms

b) Religion: Hindu

Non-Hindu

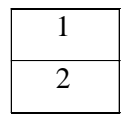

c) Family background: Rural

Urban

\begin{tabular}{|l|}
\hline 0 \\
\hline 1 \\
\hline
\end{tabular}

Enumerator: Please note that household size consists of those members who share the same kitchen and are dependent on family income/ pool income. 
2.3. Work Place: (Adults)

\begin{tabular}{|l|l|l|l|l|l|l|l|l|}
\hline Name & $\begin{array}{l}\text { Med } \\
\text { insurance }\end{array}$ & $\begin{array}{l}\text { Loss of } \\
\text { Income/d }\end{array}$ & $\begin{array}{l}\text { No. of } \\
\text { Hrs./d }\end{array}$ & $\begin{array}{l}\text { No. of } \\
\text { Paid } \\
\text { Sick } \\
\text { Leaves }\end{array}$ & $\begin{array}{l}\text { Out } \\
\text { door } \\
\text { Job } \\
\text { Y/N }\end{array}$ & $\begin{array}{l}\text { Indoor } \\
\text { Job } \\
\text { AC } \\
\text { Y/N }\end{array}$ & $\begin{array}{l}\text { Affected by } \\
\text { Factory } \\
\text { Fumes, Road } \\
\text { dust etc. Y/N }\end{array}$ \\
\hline & & & & & & & & \\
\hline & & & & & & & & \\
\hline
\end{tabular}

2.4 School/ College/ Other place

\begin{tabular}{|l|l|l|l|l|l|}
\hline Name & Place(S/C/O) & $\begin{array}{l}\text { No. of } \\
\text { Hrs. } \\
\text { spend } \\
\text { daily in } \\
\text { s/c/o }\end{array}$ & $\begin{array}{l}\text { Out door } \\
\text { Y/N }\end{array}$ & $\begin{array}{l}\text { Indoor } \\
\text { A/C }\end{array}$ & $\begin{array}{l}\text { Affected by Factory } \\
\text { fumes, Road dust } \\
\text { Etc. }\end{array}$ \\
\hline & & & & & \\
\hline & & & & & \\
\hline & & & & & \\
\hline
\end{tabular}

\section{Section 3: Health Production Model}

\subsection{General Awareness of the Households}

i) Are you aware that air pollution causes illness? Yes - 1 No - 2

ii) Kindly mark the diseases you attribute to air pollution in the list of diseases given below:

Enumerator: Please explain to the respondents that diseases mentioned below are clinically proven to be caused / aggravated by air pollution.

1) Eye/nose/throat irritation

2) Runny nose/Cold

3) Flu/Fever

4) Skin infection/Rash

5) Asthma attacks

6) Shortness of breath

7) Respiration allergy to dust \& pollen

8) Dry scratchy throat

9) Chest pain

10) Cough with phlegm

11) Dry cough

12) Bronchitis

13) Drowsiness

14) Pneumonia
15) Heart Disease

16) Cancer

17) Headache 


\subsection{General Health}

\subsubsection{Chronic Disease}

\begin{tabular}{|l|l|}
\hline Name & Disease Code \\
\hline & \\
\hline & \\
\hline & \\
\hline
\end{tabular}

Chronic Disease Code:

1) Asthma

2) $\mathrm{BP}$

3) Diabetes

4) $\mathrm{TB}$

5) Cancer

6) Heart Disease

7) Eye Disease (Cataract, Glaucoma)

8) Any Other Specify

Enumerator: Please enter the right code.

\begin{tabular}{|c|c|c|c|c|c|c|c|}
\hline \multirow[t]{2}{*}{ S.No. } & \multirow[t]{2}{*}{ Name } & \multirow{2}{*}{$\begin{array}{l}\text { Daily } \\
\text { distance } \\
\text { traveled } \\
(\mathrm{kms})\end{array}$} & \multirow[b]{2}{*}{$\begin{array}{l}\text { Daily } \\
\text { extra } \\
\text { km. } \\
\text { Travel } \\
\text { to avoid } \\
\text { pollution }\end{array}$} & \multirow[b]{2}{*}{$\begin{array}{l}\text { No. of } \\
\text { days } \\
\text { stayed } \\
\text { indoors } \\
\text { in last } \\
\text { three } \\
\text { months }\end{array}$} & \multirow[b]{2}{*}{\begin{tabular}{|l} 
Other \\
measures \\
to avoid \\
pollution \\
(mask \\
etc.)
\end{tabular}} & \multicolumn{2}{|c|}{ Mode of transport code } \\
\hline & & & & & & $\begin{array}{l}\text { Own } \\
\text { conveyance* }\end{array}$ & $\begin{array}{l}\text { Public } \\
\text { transport*** }\end{array}$ \\
\hline & & & & & & & \\
\hline & & & & & & & \\
\hline & & & & & & & \\
\hline
\end{tabular}




\subsubsection{Drinking water quality}

Filtered 1

Otherwise 0

\subsection{Indoor pollution}

a) Use of AC in summer —-Yes/ No

b) Use of chimney/ exhaust fan-—Yes / No

c) Use of heater in winter-___ Yes/ No

d) LPG used_—_- Yes/ No

e) Affected by main road dust —_— Yes/ No

f) Dampness-—— Yes/No

g) Mosquito repellent_——-Yes/No

h) Furry pet——— Yes/No

i) Carpet-——Yes/No

j) Indoor plants_——_- Yes /No

k) Incense burning —— Yes/No

l) Coal, kerosene, wood, cow dung etc.——— Yes/No

\section{Averting Activities:}

* a) AC Car

b) Non-AC car

c) Two wheeler
** a) Taxi

b) Three wheeler

c) Tempo / bus d) Cycle

\section{Section 4: Household Income}

\subsection{Consumer durable}

a) Washing machine

b) Micro-oven

c) Fridge

d) Music system

e) $\mathrm{TV}$

f) Heater

g) Geyser

h) Computer

i) Telephone

j) Vehicle (specify)

k) D V D player

1) Any other specifies

4.2. Annual Expenditure incurred by the household on the following categories (in Rs.)

a) Education

b) Household living * 
c) Recreation **

d) Travel

e) Rented house / owned house***

* Includes kitchen, toiletry, electricity, clothing, medicines, servants, annual functions / festivals, gas etc.

** Includes eating out, holidaying out of station —— travel /stay / food etc., movies picnic

*** Includes house tax, repair cost, rent, society's charges etc. incurred by household.

\subsection{Total Annual Earning of the Household Rs.}

(If you could not tell the exact income, in which of the following category your household income falls?)
a) Up to Rs.50,000
b) $50,000-1,00,000$
c) $1,00,000-2,00,000$
d) $2,00,000-4,00,000$
e) $4,00,000-8,00,000$
f) Above $8,00,000$ 


\section{Appendix D}

\section{Green Diary \\ For Health Records}

SL. No.

Respondent's Name:

Address:

Monitoring Station:

\section{List of Diseases attributed to Air Pollution:}

It has been proved clinically that the following illnesses are caused and aggravated by air pollution. If you and your family members suffer from these illnesses you are requested to keep a record of the illness and medical expense incurred by you on your family members and yourself every week by mentioning the date of medication during that week. If the diseases mentioned below do not match with the ones that you usually suffer from, please write the names of the diseases relevant for you and your family.

1) Headache

2) Eye/nose/throat irritation

3) Runny nose/Cold

4) Flu/Fever

5) Skin infection/Rash

6) Asthma attacks

7) Shortness of breath

8) Respiration allergy to dust \& pollen

9) Dry scratchy throat

10) Chest pain

11) Cough with phlegm

12) Dry Cough

13) Bronchitis

14) Drowsiness

15) Pneumonia

16) Heart Disease

17) Cancer

\section{Instructions for filling up the Health Diary}

Filling the diary will take only 5 minutes from your schedule for a week..

You are requested to enter all medical expenses for you and each of your family members separately with date on the day you incur such expenses. Medical expense should include cost of medicines bought with or without consulting a doctor, doctor's fee, cost of homeopathic, ayurvedic medicines, etc. 
Mitigating Activities

\begin{tabular}{|c|c|c|c|c|c|c|c|c|c|c|}
\hline \multirow[t]{2}{*}{ Name } & \multirow[b]{2}{*}{$\begin{array}{l}\text { Name of } \\
\text { disease/ } \\
\text { symptom } \\
\text { code (as } \\
\text { mentioned } \\
\text { in 3.1) }\end{array}$} & \multirow{2}{*}{$\begin{array}{l}\text { No of } \\
\text { sick } \\
\text { days in } \\
\text { last } \\
\text { week }\end{array}$} & \multicolumn{6}{|c|}{ Medical expenditure } & & \\
\hline & & & $\begin{array}{l}\text { Travel } \\
\text { Cost to } \\
\text { Doctor's } \\
\text { Clinic }\end{array}$ & $\begin{array}{l}\text { Total } \\
\text { Time } \\
\text { (waiting } \\
\& \\
\text { Travel) }\end{array}$ & $\begin{array}{l}\text { Accom } \\
\text { panying } \\
\text { Person } \\
(y / n)\end{array}$ & $\begin{array}{l}\text { Doctor's } \\
\text { Fees }\end{array}$ & $\begin{array}{l}\text { Cost of } \\
\text { medicine }\end{array}$ & $\begin{array}{l}\text { No. of days } \\
\text { medicine } \\
\text { taken }\end{array}$ & $\begin{array}{l}\text { Absence } \\
\text { from } \\
\text { work }\end{array}$ & $\begin{array}{l}\text { Total } \\
\text { Cost }\end{array}$ \\
\hline & & & & & & & & & & \\
\hline & & & & & & & & & & \\
\hline
\end{tabular}

\section{Hospitalization}

\begin{tabular}{|c|c|c|c|c|c|c|}
\hline Week & Name & Disease & $\begin{array}{l}\text { Days of } \\
\text { Hospitalization }\end{array}$ & Govt/Private & $\begin{array}{l}\text { Attendant } \\
\text { paid/Family } \\
\text { member }\end{array}$ & $\begin{array}{l}\text { Total } \\
\text { Cost }\end{array}$ \\
\hline & & & & & & \\
\hline & & & & & & \\
\hline & & & & & & \\
\hline & & & & & & \\
\hline & & & & & & \\
\hline & & & & & & \\
\hline
\end{tabular}





\section{(c) (1) (9)}

This work is licensed under a

Creative Commons

Attribution - NonCommercial - NoDerivs 3.0 License.

To view a copy of the license please see:

http://creativecommons.org/licenses/by-nc-nd/3.0/

This is a download from the BLDS Digital Library on OpenDocs

http://opendocs.ids.ac.uk/opendocs/ 